Check for updates

Cite this: Mater. Adv., 2020, 1,2043

Received 18th June 2020,

Accepted 24th July 2020

DOI: $10.1039 / \mathrm{d} 0 \mathrm{ma} 00432 \mathrm{~d}$

rsc.li/materials-advances

\section{Tuning protein delivery from different architectures of layer-by-layer assemblies on polymer films $\dagger$}

\author{
Giovanne Delechiave, Alliny F. Naves, Elayaraja Kolanthai, Rubens A. da Silva, \\ Raphael C. Vlasman, Denise F. S. Petri, iD Roberto M. Torresi and \\ Luiz H. Catalani iD *
}

\begin{abstract}
In the past two decades, the fabrication of nanolayer coatings on polymeric materials has triggered considerable interest in the tissue-engineering field. Layer-by-Layer (LbL) assembly has attracted substantial attention due to being a convenient and low-cost method to coat materials with biomolecules while keeping their original biofunctionalities. This work aims to access a deeper understanding of the processes of adsorption and desorption of proteins by studying different architectures for the loading and release of model proteins on spin-coated flat surfaces of biodegradable polyesters such as poly( $\varepsilon$-caprolactone) ( $P C L)$ and poly(L-lactic acid) (PLLA) by the LbL technique. Surfaces of Si-wafers coated with PCL and PLLA were used as substrates for deposition of model proteins such as bovine serum albumin and lysozyme using heparin and chitosan as a pair of polyelectrolytes for LbL assembly. The analysis of the attributes of these protein reservoirs such as the protein layer position, layer thickness, surface morphology, protein adsorption and desorption quantification and kinetics was performed by ellipsometry, atomic force microscopy, fluorescence microscopy, and quartz-crystal microbalance with enhanced dissipation measurements. A homogenous LbL coating on the surface of the polyester films was achieved by assembling ten layer-pairs of reservoirs. The release profiles were evaluated, and the results showed an intricate dependence on the protein volume charge density and its relation to coacervation/complexation processes with both polyelectrolytes. Our results clearly suggest that the protein delivery kinetics can be fully controlled by precisely positioning the protein within the assembly (bottom vs. top position). They also suggest that the size and total charge of the protein are key factors for controlling its total load in the assembly.
\end{abstract}

\section{Introduction}

The combination of bioactive molecules and biodegradable scaffolds gives new possibilities in regenerative medicine. In addition to physical support for cell attachment, these scaffolds can also provide the appropriate mechanical and biological signals to initiate and guide the growth of new tissue. Efforts have been made to include a bioactive proteic material on the surface of scaffolds, as well as to develop the means to control its delivery. Several articles report the use of Layer-by-Layer (LbL) assembly as an efficient architecture to resolve this quest and open perspectives to apply these reservoirs in tissue engineering. ${ }^{1-5}$

Departamento de Química Fundamental, Instituto de Química, Universidade de São Paulo, Av. Prof. Lineu Prestes, 748, CP 26077, 05508-000, São Paulo, Brazil.

E-mail: catalani@usp.br; Tel: +55(11)30911811

$\dagger$ Electronic supplementary information (ESI) available. See DOI: 10.1039/ d0ma00432d
LbL assembly, complexation between oppositely charged polyelectrolytes, ${ }^{6}$ has been applied to a myriad of surfaces (metal, ${ }^{7}$ glass, ${ }^{8}$ polymers, ${ }^{9}$ etc.) and shapes (flat, ${ }^{1}$ porous, ${ }^{9}$ spherical, ${ }^{10}$ etc.). The main applications include drug delivery devices used to incorporate biomolecules of interest ${ }^{10}$ or to act as a barrier for sustained release. ${ }^{11}$ In the case of signaling biomolecules, some examples include the fabrication of poly(lacticco-glycolic) acid (PLGA) membranes coated with polyelectrolyte multilayers comprised of poly(beta-amino esters) and poly(acrylic acid) for entrapment of bone morphogenetic protein-2 and plateletderived growth factor, combined or not in the same device. The sustained dual release of growth factors could induce bone repair in a critical-size defect model in rat calvaria and accelerate bone reconstruction. ${ }^{12}$ In this same trend, the building of nano reservoirs made from chitosan/bone morphogenetic protein-7 (BMP7) multilayers on polycaprolactone (PCL) fibers was able to accelerate in vivo bone mineralization and regeneration. ${ }^{13}$ The loading of bFGF in PLGA microspheres, ${ }^{14,15}$ or free-standing films, ${ }^{16}$ and 
vascular endothelial growth factor in PLLA $^{17}$ and $\operatorname{PLGA}^{14}$ electrospun fibers also demonstrates the use of LbL for storage of signaling molecules.

The recent demonstration of the use of heparin (Hep) and chitosan (Chi) solutions loaded with acid or basic fibroblast growth factors (aFGF and bFGF, respectively) opens questions regarding the role of the total charge of the protein in the event. One of the advantages observed using co-solutions of polyelectrolytes and proteins is the long-term storage detected for such LbL reservoirs. ${ }^{18}$ Even after nine months, the (Hep/Chi) multilayers kept the activity of the embedded growth factors. Also, the preparation of co-solutions with suitable polyelectrolytes creates a mild environment that prevents protein degradation in solution due to the loss of its tertiary structure, enabling the protein to maintain its stability for the prolonged periods required to prepare the reservoirs.

Therefore, the current work aims to create LbL reservoirs of Hep/Chi assembled on polymeric films of PCL and PLLA, using acidic and basic model proteins, namely lysozyme (LYS) and bovine serum albumin (BSA). We have presented a systematic study of reservoir growth onto these polymeric surfaces, including the development of control over the amount of loaded proteins and their release, by elucidating essential parameters in the LbL preparation process. In this way, we intend to gather essential information for the development of reservoirs containing new cell signaling molecules and their application in tissue engineering.

\section{Materials and methods}

\subsection{Materials}

PCL $\left(\bar{M}_{\mathrm{w}} 80000 \mathrm{~g} \mathrm{~mol}^{-1}\right.$, Aldrich, USA) and PLLA (intrinsic viscosity $0.32 \mathrm{~g} \mathrm{dL}^{-1}, \bar{M}_{\mathrm{w}} 130000 \mathrm{~g} \mathrm{~mol}^{-1}$, Purasorb PL 32) were used to prepare thin spin-coated films supported on Si-wafers (University Wafers, USA) with a native $\mathrm{SiO}_{2}$ layer. LYS and BSA (pI 10.2 and 5.1, respectively, experimentally obtained on a Zetasizer Nano Zs - Malvern), from Sigma (USA), were chosen as model proteins to assemble the reservoirs. Heparin sodium salt $\left(\bar{M}_{\mathrm{w}} 15000 \mathrm{~g} \mathrm{~mol}^{-1}\right)$ was from CalBiochem (USA). Chitosan $\left(\bar{M}_{\mathrm{w}} 83600 \mathrm{~g} \mathrm{~mol}^{-1}\right)$, from Aldrich (USA), was purified before use. ${ }^{19}$ Polyethyleneimine (PEI, $\bar{M}_{\mathrm{w}} 25000 \mathrm{~g} \mathrm{~mol}^{-1}$ ) and fluorescein 5-isothiocyanate (FITC), from Aldrich (USA), and chloroform, ethanol, acetic acid, $\mathrm{CaCl}_{2}, \mathrm{P}_{2} \mathrm{O}_{5}$, and $\mathrm{NaOH}$, from Synth (Brazil), were used as received. Chloroform, from Synth (Brazil), was dried under $\mathrm{P}_{2} \mathrm{O}_{5}$ and distilled before use. Ultrapure water of Milli-Q quality $\left(18.2 \mathrm{M} \Omega \mathrm{cm}\right.$ at $25{ }^{\circ} \mathrm{C}$, Milli-Q Gradient, Millipore, USA) was used for all the experiments and rinsing steps.

\subsection{Methods}

2.2.1 Turbidimetry assay. The interactions of Hep with LYS and Chi with BSA were analyzed initially through turbidimetry by measuring the transmittance at $500 \mathrm{~nm}$ using a MultiSpec1501 spectrophotometer, Shimadzu, at $23{ }^{\circ} \mathrm{C}$. Solutions with 0 , $0.25,1.0,1.5$, and 2.0 polyelectrolyte: protein mass ratios were prepared from stock protein solutions of LYS and BSA
(1 $\mathrm{mg} \mathrm{mL} \mathrm{m}^{-1}$ in water) and polyelectrolyte stock solutions of Hep (1 $\mathrm{mg} \mathrm{mL} \mathrm{m}^{-1}$ in $0.15 \mathrm{M}$ saline solution) and Chi $\left(1 \mathrm{mg} \mathrm{mL}^{-1}\right.$ in $\mathrm{NaCl} 0.15 \mathrm{M}$ and $2 \%$ acetic acid). The initial protein concentration was $0.3 \mathrm{mg} \mathrm{mL}{ }^{-1}$. The solutions were left under room temperature at rest for $15 \mathrm{~min}$ (same conditions as the LbL assembly), followed by soft stirring (homogenization) before the assay.

2.2.2. Circular dichroism assay. The interaction effect of the polyelectrolyte over the protein structure is analyzed by circular dichroism (Jasco 815-A spectrophotometer) at $23{ }^{\circ} \mathrm{C}$. For Hep and Lys, solutions with 0, 0.10, 0.15, 0.25, 0.5, 1.0, 1.5, and 2.0 polyelectrolyte per protein mass ratios were prepared from a stock protein solution of LYS $\left(1 \mathrm{mg} \mathrm{mL} \mathrm{mL}^{-1}\right.$ in water $)$ and a polyelectrolyte stock solution of Hep $\left(1 \mathrm{mg} \mathrm{mL} \mathrm{m}^{-1}\right.$ in $0.15 \mathrm{M}$ saline solution). The initial protein concentration was $0.06 \mathrm{mg} \mathrm{mL} \mathrm{m}^{-1}$. Before obtaining the CD spectra, the solutions were left at room temperature at rest for $15 \mathrm{~min}$ (same conditions as the LbL assembly). For Chi and BSA, solutions with 0, 0.5, 1.0, $1.5,2.0,4.0$, and 8.0 polyelectrolyte per protein ratios were prepared from a stock protein solution of BSA $\left(1 \mathrm{mg} \mathrm{mL}^{-1}\right.$ in water) and a polyelectrolyte stock solution of Chi $\left(1 \mathrm{mg} \mathrm{mL} \mathrm{m}^{-1}\right.$ in $0.15 \mathrm{M}$ saline solution and $2 \%$ acetic acid). Before obtaining the CD spectra, the solutions were left at room temperature at rest for 15 min (same conditions as the LbL assembly), followed by soft stirring (homogenization).

2.2.3. Isothermal titration calorimetry assay. The heat quantification of the interaction between the protein and polyelectrolyte was performed by Isothermal Titration Calorimetry (ITC, MicroCal ITC) at $23{ }^{\circ} \mathrm{C}$. Primarily, both proteins were dialyzed under phosphate buffer $(10 \mu \mathrm{M}, \mathrm{NaCl} 150 \mu \mathrm{M}$ at $\mathrm{pH}=7.0$ ), followed by sonic degassing. 29 injections of $10 \mu \mathrm{L}$ of polyelectrolyte solution were added to the protein solution with a delay of $300 \mathrm{~s}$. The reference power was $10 \mu \mathrm{cal} \mathrm{s}{ }^{-1}$ for the Hep and LYS experiment and $2 \mu \mathrm{cal} \mathrm{s}{ }^{-1}$ for the Chi and BSA experiment. The initial protein concentration was $152 \mu \mathrm{M}$ for LYS and $20 \mu \mathrm{M}$ BSA in an initial volume of $2 \mathrm{~mL}$. The polyelectrolyte stock solution concentrations were $228 \mu \mathrm{M}$ for Hep and $125 \mu \mathrm{M}$ for Chi. All solutions were prepared with the same solution as used for dialysis, phosphate buffer $(10 \mu \mathrm{M}$, $\mathrm{NaCl} 150 \mu \mathrm{M}$ at $\mathrm{pH}=7.0$ ).

2.2.4. Layer-by-layer assembly. LbL assemblies of different cation and anion composition mixtures were assembled over three different materials as a base: bare Si-wafers, Si-wafers covered by a thin layer of polyester or a gold flat surface (for QCM-D measurements) also covered with a thin polyester layer. All three bases were next covered with a single layer of PEI. Before the experiments, the Si-wafers were cut into square shapes $(1.5 \mathrm{~cm} \times 1.5 \mathrm{~cm})$, cleaned with Extran ${ }^{\circledR}(10 \% \mathrm{v} / \mathrm{v}$, Merck), extensively rinsed with water, and additionally rinsed with ethanol, both in an ultrasound bath for $15 \mathrm{~min}$. After drying with a compressed air stream, the Si-wafers were activated using UV light (UV/ozone ProCleaner, Bioforce Nanosciences) and characterized by ellipsometry. Spin-coated films were deposited on the activated Si-wafers (Spin Coater Headway, Garland, USA) using solutions of PCL and PLLA at $10 \mathrm{mg} \mathrm{mL}^{-1}$ prepared in chloroform. The thin spin-coated films (thickness about $100 \mathrm{~nm}$ ) 
Table 1 LbL thickness determined by ellipsometry and AFM measurements

\begin{tabular}{|c|c|c|}
\hline \multirow[b]{2}{*}{ Samples } & \multicolumn{2}{|c|}{ Thickness (nm) } \\
\hline & Ellipsometry & AFM \\
\hline$\left(\mathrm{Si} / \mathrm{SiO}_{2} / \mathrm{PEI}\right)(\mathrm{Hep} / \mathrm{Chi})_{20}$ & $82 \pm 1$ & $75 \pm 17$ \\
\hline$\left(\mathrm{Si} / \mathrm{SiO}_{2} / \mathrm{PEI}\right)(\mathrm{Hep}+\mathrm{BSA} / \mathrm{Chi})_{20}$ & $80 \pm 1$ & $93 \pm 11$ \\
\hline$\left(\mathrm{Si} / \mathrm{SiO}_{2} / \mathrm{PEI}\right)(\mathrm{Hep} / \mathrm{Chi}+\mathrm{LYS})_{20}$ & $70 \pm 1$ & $83 \pm 6$ \\
\hline$\left(\mathrm{Si} / \mathrm{SiO}_{2} / \mathrm{PEI}\right)(\mathrm{Hep} / \mathrm{Chi})_{10}$ & $34 \pm 5$ & $34 \pm 2$ \\
\hline$\left(\mathrm{Si} / \mathrm{SiO}_{2} / \mathrm{PEI}\right)(\mathrm{Hep}+\mathrm{BSA} / \mathrm{Chi})_{10}$ & $29 \pm 3$ & $40 \pm 2$ \\
\hline$\left(\mathrm{Si} / \mathrm{SiO}_{2} / \mathrm{PEI}\right)(\mathrm{Hep} / \mathrm{Chi}+\mathrm{LYS})_{10}$ & $39 \pm 6$ & $45 \pm 5$ \\
\hline$\left(\mathrm{Si} / \mathrm{SiO}_{2} / \mathrm{PEI}\right)(\mathrm{Hep} / \mathrm{Chi})_{4}(\mathrm{Hep}+$ & $29 \pm 1$ & n.d. \\
\hline $\begin{array}{l}\mathrm{BSA} / \mathrm{Chi})_{3}(\mathrm{Hep} / \mathrm{Chi})_{3} \\
(\mathrm{Si} / \mathrm{SiO} / \mathrm{PEI})(\mathrm{Hen} / \mathrm{Chi})_{1}(\mathrm{Hep} / \mathrm{Chi}+\end{array}$ & & \\
\hline $\begin{array}{l}\left(\mathrm{Si} / \mathrm{SiO}_{2} / \mathrm{PEI}\right)(\mathrm{Hep} / \mathrm{Chi})_{4}(\mathrm{Hep} / \mathrm{Chi}+ \\
\mathrm{LYS})_{3}(\mathrm{Hep} / \mathrm{Chi})_{3}\end{array}$ & $25 \pm 2$ & n.d. \\
\hline
\end{tabular}

were used as substrates for the assembly of LbL reservoirs using Hep/Chi multilayers and the model proteins. As control experiments, reservoirs with 20 layer-pairs (LP) were assembled on bare Si-wafers to allow the characterization of the reservoirs by ellipsometry (Table 1). These controls were prepared because the thin spin-coated polyester films absorb in the wavelength of the incident beam in the ellipsometer, making impossible the characterization of the LbL assembly on top of them by this technique.

The solutions for LbL assembly were prepared according to a methodology described previously. ${ }^{18}$ PEI $2.5 \mathrm{mg} \mathrm{mL}^{-1}$ was prepared in water $(\mathrm{pH}=10.7)$. Stock solutions of Hep $1 \mathrm{mg} \mathrm{mL}{ }^{-1}$ and Chi $1 \mathrm{mg} \mathrm{mL} \mathrm{mL}^{-1}$ were prepared in $\mathrm{NaCl}$ $150 \mathrm{mmol} \mathrm{L}^{-1}$ (physiological conditions), and 2\% acetic acid $(\mathrm{v} / \mathrm{v})$ was added to the chitosan solution. The dipping solutions were dilutions Hep $0.1 \mathrm{mg} \mathrm{mL}^{-1}$ and Chi $0.1 \mathrm{mg} \mathrm{mL}^{-1}$ in $\mathrm{NaCl}$ $150 \mathrm{mmol} \mathrm{L}^{-1}(\mathrm{pH}=6.1$ and $\mathrm{pH}=3.7$, respectively). A co-solution of Hep $0.1 \mathrm{mg} \mathrm{mL}^{-1}$ with the model protein BSA $0.1 \mu \mathrm{g} \mathrm{mL}^{-1}$ $(\mathrm{Hep}+\mathrm{BSA}, \mathrm{pH}=6.7)$ and a co-solution of Chi $0.1 \mathrm{mg} \mathrm{mL}^{-1}$ with the model protein LYS $0.1 \mu \mathrm{g} \mathrm{mL} \mathrm{m}^{-1}(\mathrm{Chi}+\mathrm{LYS}, \mathrm{pH}=3.0)$ were used as dipping solutions to build the reservoirs described in Table 1. PEI was adsorbed only in the primer layer to enable uniform LbL assembly. PEI deposition was performed by dipping the Si-wafers for 15 minutes, while for the spin-coated polyester films it was carried out overnight, followed by three rinsing steps and drying under an air stream. After the deposition of PEI, the Hep/Chi multilayers as well as the Hep + BSA/Chi or Hep/Chi + LYS reservoirs were assembled in an LbL manner by dipping the substrates (Si-wafers covered or not with polyester spin-coated films) alternately into polyelectrolyte solutions for $10 \mathrm{~min}$, followed by three rinsing steps of one minute each. After each adsorption step, the substrates were dried under an air stream. The multilayers $(\mathrm{Hep} / \mathrm{Chi})_{10}$, $(\mathrm{Hep}+\mathrm{BSA} / \mathrm{Chi})_{10}$, and $(\mathrm{Hep} / \mathrm{Chi}+$ LYS $)_{10}$, and the hybrid $(\mathrm{Hep} / \mathrm{Chi})_{4}(\mathrm{Hep}+\mathrm{BSA} / \mathrm{Chi})_{3}(\mathrm{Hep} / \mathrm{Chi})_{3}$ and $(\mathrm{Hep} / \mathrm{Chi})_{4}(\mathrm{Hep} / \mathrm{Chi}+\mathrm{LYS})_{3}(\mathrm{Hep} / \mathrm{Chi})_{3}$ were assembled on top of PCL or PLLA spin-coated films to measure the protein release according to the position of the reservoir in the multilayers. In addition, the reservoirs (Hep + BSA/Chi) ${ }_{10}$ and (Hep/ Chi + LYS $)_{10}$ were built on polyester films using co-solutions in which the concentration of BSA or LYS was raised to 1,10 or $100 \mu \mathrm{g} \mathrm{mL}^{-1}$ (by keeping the polyelectrolytes at $0.1 \mathrm{mg} \mathrm{mL}^{-1}$ ) to evaluate the stability of the LbL reservoirs according to the increase of protein concentration in the co-solution.
2.2.5. Protein labeling with FITC. FITC was used to label the BSA and LYS proteins by a chemical route. Briefly, $10 \mathrm{mg}$ of FITC was dissolved in $10 \mathrm{~mL}$ DMSO $\left(1 \mathrm{mg} \mathrm{mL} \mathrm{mL}^{-1}\right) .100 \mathrm{mg}$ of BSA or LYS powder was dissolved in $100 \mathrm{~mL}$ carbonate buffer (0.1 $\mathrm{mg} \mathrm{mL}^{-1}, \mathrm{pH}$ 9.8). The FITC solution was added drop-bydrop into a protein solution of BSA or LYS, mixed at $4{ }^{\circ} \mathrm{C}$ for 30 min under dark conditions, and stored at $4{ }^{\circ} \mathrm{C}$ overnight. Dialysis membranes (MWCO $14 \mathrm{kDa}$ for BSA, and $8 \mathrm{kDa}$ for LYS, Sigma) were used for purification against deionized water during a period of 7 days with the water replaced twice per day, followed by freeze-drying. The isoelectric points of BSA-FITC and LYS-FITC were experimentally determined as 4.3 and 10.5, respectively (Zetasizer Nano Zs - Malvern). Characterization by fluorescence and UV-vis spectroscopy confirmed the labeling $\left(\lambda_{\max } 516 \mathrm{~nm}\right)$ of FITC with BSA and LYS. Green fluorescence molecule labeled BSA and LYS were further used for the LbL experiment. The reservoirs were built on polyester films using co-solutions of BSA-FITC or LYS-FITC $\left(100 \mu \mathrm{g} \mathrm{mL}^{-1}\right)$ with polyelectrolytes $\left(0.1 \mathrm{mg} \mathrm{mL}^{-1}\right)$ to investigate the protein loading in the LbL construction by fluorescence microscopy (Microscope Zeiss Axiovert 200).

2.2.6. Layer thickness measurement. Ellipsometry measurements were carried out using DRE equipment model 6ELX02-5 using an incident laser beam ( $\mathrm{He}-\mathrm{Ne}, 632.8 \mathrm{~nm}$ ) at $70^{\circ}$, which covers a surface area of around $3 \mathrm{~mm}^{2}$ of the sample. A multilayer model comprised of the substrate (Si-wafer), the $\mathrm{SiO}_{2}$ layer, the $\mathrm{LbL}$ multilayers, and air was employed for data interpretation. The thickness $\left(d_{\mathrm{k}}\right)$ and the refractive index $\left(n_{\mathrm{k}}\right)$ of the unknown layer (LbL multilayers in our case) are evaluated from the changes in phase $(4)$ and amplitude $(\Psi)$ related to the incident beam using the Drude and Fresnel relations, the fundamental equation of ellipsometry (eqn (1)), and iterative calculations through Jones matrixes. ${ }^{20}$

$$
e^{i \Delta} \tan \Psi=R_{\mathrm{p}} / R_{\mathrm{S}}=f\left(n_{\mathrm{k}}, d_{\mathrm{k}}, \lambda, \varphi\right)
$$

Here $R_{\mathrm{p}}$ and $R_{\mathrm{s}}$ are the total reflection coefficients for the parallel and perpendicular components of the electric field and depend on the incident angle $\varphi$, the beam wavelength $\lambda$, the refractive index $n_{\mathrm{k}}$, and the thickness $d_{\mathrm{k}}$ of each layer in the model.

For calculation purposes, the refractive indexes of the components are considered as constants, assuming the films being uniform and isotropic. The refractive indexes were assumed as 3.88 for $\mathrm{Si}, 1.462$ for $\mathrm{SiO}_{2}$, and 1 for air. Due to the small thickness of the LbL multilayers, their refractive index was assumed to be constant at 1.51 (generic values for proteins due to the presence of model proteins), and despite their slightly heterogeneous morphology, they were assumed to be uniform and isotropic films. Although this procedure gives slightly incorrect values for the absolute film thickness, it allows quick and precise determination of the relative film thicknesses. Each data point in the graphs (thickness versus layer number) is obtained from random measurements at two different points of the substrate surface. Samples were prepared in duplicate.

2.2.7. QCM-D measurements. Before use, the quartz crystals were thoroughly cleaned to remove any organic contaminants present, according to a procedure described elsewhere. ${ }^{21,22}$ 
PCL thin films were obtained by spin coating (Ossila spin coater, UK). The coatings were obtained by adding $30 \mu \mathrm{L}$ of the polymer solution at $8 \mathrm{~g} \mathrm{~L}^{-1}$ over quartz crystals coated with gold (QSense, Sweden) operating at $3000 \mathrm{rpm}$ for $30 \mathrm{~s}$. To ensure a continuous thin film, the temperature and relative humidity was kept constant at $(24 \pm 1){ }^{\circ} \mathrm{C}$ and $(30 \pm 5) \%$, respectively. The PCL coated quartz crystal was named Au/PCL.

The adsorption of PEI, using a solution with concentration $2.5 \mathrm{mg} \mathrm{mL}^{-1}$, was measured overnight in flow on Au/PCL. PEI became a surface suitable for heparin immobilization, which is warranted by the formation of hydrogen bonds between the amine group residues of the PEI and the hydroxyl groups of the disaccharide. Due to the difference in charge densities between the polyelectrolytes, chitosan (positively charged) was immobilized on heparin (negatively charged). The adsorption and washing tests were performed in flow with the aid of a peristaltic pump. The interaction time of the polyelectrolytes (concentration at $0.1 \mathrm{mg} \mathrm{mL}^{-1}$ ) for the adsorption assays was 20 minutes, followed by 8 minutes of washing in $\mathrm{NaCl}$ solution $(0.15 \mathrm{M})$. The BSA and LYS proteins were adsorbed on the multilayers using co-solutions with the polyelectrolytes (BSA in the solution of Hep and LYS in the Chi solution), where the concentrations of both proteins were $100 \mu \mathrm{g} \mathrm{mL}{ }^{-1}$. This procedure was repeated 10 times. The following systems were coded as $(\mathrm{Au} / \mathrm{PCL} / \mathrm{PEI})(\mathrm{Hep} / \mathrm{Chi})_{10} ;(\mathrm{Au} / \mathrm{PCL} / \mathrm{PEI})(\mathrm{Hep}+\mathrm{BSA} / \mathrm{Chi})_{10}$ and $(\mathrm{Au} / \mathrm{PCL} / \mathrm{PEI})(\mathrm{Hep} / \mathrm{Chi}+\mathrm{LYS})_{10}$, respectively.

A QCM-D experiment was performed for each modification step on the substrate using a Q-Sense E4 (Q-Sense - Sweden) in a flow cell module. For these measurements an AT-cut quartz crystal covered with $\mathrm{Au}(d=14 \mathrm{~mm})$ was used, with a fundamental frequency of $5 \mathrm{MHz}$. All steps were performed at a flow rate of $(320 \pm 20) \mu \mathrm{L} \min ^{-1}$ at $(25.00 \pm 0.05){ }^{\circ} \mathrm{C}$. The changes in resonance frequency $\left(\Delta f_{n}\right)$ and dissipation $\left(\Delta D_{n}\right)$, where $n$ denotes the fundamental tone recorded from the 5 th to the 13th overtones, were simultaneously monitored as a function of time. For acoustically rigid films, the mass variation can be calculated from the resonance frequency variation, as described in Sauerbrey's equation (eqn (2)): ${ }^{21,22}$

$$
\Delta f_{n}=-\left(\frac{2 f_{n}^{2}}{n^{2} \sqrt{\mu \rho}}\right) \times \frac{\Delta m}{A}=-\frac{\Delta m}{C \times A}
$$

where $\Delta f$ is the measured shift in resonance frequency $(\mathrm{Hz}), A$ is the piezoelectric active area of the crystal corresponding to the exciting electrode exposed to the working environment, $\rho$ is the quartz density $\left(2.648 \mathrm{~g} \mathrm{~cm}^{-3}\right), \mu$ is the shear modulus (2.947 $10^{11} \mathrm{~g} \mathrm{~cm}^{-1} \mathrm{~s}^{-2}$ ), and $f_{n}$ is the crystal frequency for the $n$th overtone ( $5 \mathrm{MHz}$ for the fundamental tone). The value of the constant $C$ is $17.9 \pm 0.5 \mathrm{ng} \mathrm{cm}{ }^{-2} \mathrm{~Hz}^{-1} \cdot{ }^{23}$ A decrease in the resonance frequency indicates an increase in mass. With QCM-D it is also possible to measure changes in $\Delta D_{n}$ (related to the changes in the viscoelastic properties of the film), so that, for non-rigid films, the dissipation factor can be calculated by eqn (3):

$$
\Delta D=\frac{E_{\mathrm{dis}}}{2 \pi E_{\mathrm{sto}}}
$$

where $E_{\mathrm{dis}}$ is the energy dissipated, and $E_{\text {sto }}$ is the energy stored during oscillation. ${ }^{24,25}$

2.2.8. AFM analyses. The morphologies of LbL reservoirs built on polyester films, as well as on Si-wafers, were analyzed through Atomic Force Microscopy (AFM) using a Pico SPM-LE (Molecular Imaging) instrument. The images were measured in air at room temperature using intermittent contact mode (AAC mode) with silicon cantilevers operating at around $300 \mathrm{kHz}$. The topographic profiles refer to scanning areas of $(10 \mu \mathrm{m} \times$ $10 \mu \mathrm{m})$ or $(2.5 \mu \mathrm{m} \times 2.5 \mu \mathrm{m})$ with a resolution of $(512 \times 512)$ pixels. Steps made of cuts with blades in the LbL reservoirs were used to measure the thickness by AFM. The image processing and determination of roughness through the root mean square (r.m.s.) values were performed in the free software WSxM $4.0 .^{26}$

2.2.9. Study of protein loading and release. In vitro release of BSA and LYS from the reservoirs was carried out using phosphate-buffered saline (PBS, $\mathrm{pH}$ 7.4) as a dissolution medium. The multilayers supported on spin-coated films of PCL or PLLA (around $2.5 \mathrm{~cm}^{2}$ ) were placed inside a glass vial containing $1.3 \mathrm{~mL}$ of PBS and incubated at $37{ }^{\circ} \mathrm{C}$ with humidity control. The released protein solution $(100 \mu \mathrm{L})$ was collected at different time points ( $3 \mathrm{~h}, 6 \mathrm{~h}, 12 \mathrm{~h}$, and 2, 4, 8, 16, and 32 days), and the same amount of fresh PBS was added into a glass vial. The amount of BSA release from the LbL reservoirs was estimated using an ELISA kit (\#F030, Cygnus Technologies). Further, the LYS-FITC loaded reservoir was also investigated by in vitro release in PBS. The pre-determined time-point collected protein solutions were analyzed using a fluorescence (PerkinElmer) spectrophotometer with an inbuilt xenon lamp exciting at $490 \mathrm{~nm}$. The amount of LYS-FITC released from the reservoirs was determined using standard calibration curves. Release assays were performed in triplicate for each reservoir.

2.2.10. Sample naming system. Samples are named by listing consecutively their layers, with their components in parentheses, followed by a subscript number as the multiplicity $(n)$ of the layer: (base)(negative layer/positive layer) ${ }_{n}$."Base", stands for the surface $\left(\mathrm{Si} / \mathrm{SiO}_{2}\right.$ or $\left.\mathrm{Au}\right)$ covered with polyester (PCL or PLLA), and PEI as the first polyelectrolyte layer, "negative layer" is Hep, or Hep + BSA or HEP + BSA-FITC mixtures, and "positive layer" is Chi, or Chi + LYS or Chi + LYS-FITC mixtures.

2.2.11. Statistical analysis. The data are expressed as the mean \pm standard deviation. Statistical analysis was performed using the two-population Student's $t$-test. Similar letters indicate no statistically significant differences.

\section{Results and discussion}

Layer-by-layer self-assembly is a simple construct made from alternate adsorption of a positive and a negative polyelectrolyte on a substrate material such as glass, metal, polymers, etc., where its stability is controlled by electrostatic interactions, hydrogen bonding or other secondary interactions. In this technique, the substrate also plays an important role based on its wettability and surface charge. We chose PCL and PLLA 
as two substrates showing different wettability and degradability rate, to test the storage of two model proteins of different charges - BSA and LYS - in between heparin and chitosan multilayers. Since BSA presents a pI of 5.1 (experimentally obtained, Zetasizer Nano Zs - Malvern), it is, therefore, negatively charged at neutral pHs; its inclusion in the reservoir was provided by the use of a co-solution with Hep. Likewise, the pI value for LYS is 11.5 (experimentally obtained, Zetasizer Nano Zs - Malvern) and it was included by the use of a co-solution with Chi. The inclusion of both proteins was tested in assemblies of 20 and 10 layer-pairs. Also, the inclusion of proteins only in the inner layers was examined to test eventual barrier effects on the release profile.

\subsection{Analyses of protein-polyelectrolyte interactions}

Protein inclusion on the LbL assemblies was provided by the use of a co-solution with a polyelectrolyte of the same bulk charge. The central hypothesis is that the protein will interact with the superficial layer of the polyelectrolyte of opposite charge. It is, therefore, significant to understand beforehand the interaction of the opposed charge pairs Chi-BSA and Hep-LYS.

A turbidimetric titration assay was used to access the formation of insoluble protein-polyelectrolyte complexes, in the form of coacervates. The experiment consisted of UV-vis analysis of progressive addition of polyelectrolytes to a fixed concentration of protein solution, qualifying the phase separation of the complexes LYS-Hep or BSA-Chi by the change in the transmittance values. Fig. 1A shows the progressive attenuation of the transmittance at $500 \mathrm{~nm}$ of a LYS solution with an increasing concentration of Hep. At a molar ratio of 0.25 for the Hep:LYS co-solution, a reduction of $25 \%$ in the transmittance is observed, showing that a coacervate is readily formed. With increasing molar ratio, the attenuation of transmittance levels up as a result of saturation of the interaction, evidencing the strong interaction between Hep and LYS. Contrarily, Fig. 1A shows a minimal change in transmittance for the Chi:BSA solution, probably due to a much weaker interaction between Chi and BSA, despite the opposite charge of the components at the working $\mathrm{pH}$.

Circular dichroism can also be used to confirm the complex formation by observing changes in the secondary structure of the protein. Likewise, CD spectra were acquired for the protein solution under progressive increments of the polyelectrolyte, in the region of 200-250 nm. Fig. 1B shows a progressive change in the absorption spectra when Hep is added to a LYS solution. This result seems to relate to the partial loss of the $\alpha$-helix structure, with stabilization at a higher Hep:LYS ratio. Similar results were observed by Billsten et $a .^{27}$ for LYS adsorption over silica nanoparticles. For the pair Chi:BSA, the changes are more prominent, with a continuous alteration at higher mass ratios, suggesting denaturation of the protein structure. Pristine BSA contains $67 \%$ helical structures and $23 \%$ extended chain configurations. ${ }^{28}$ The changes observed in Fig. 1C can be correlated to the loss of $\alpha$-helices and an increase of
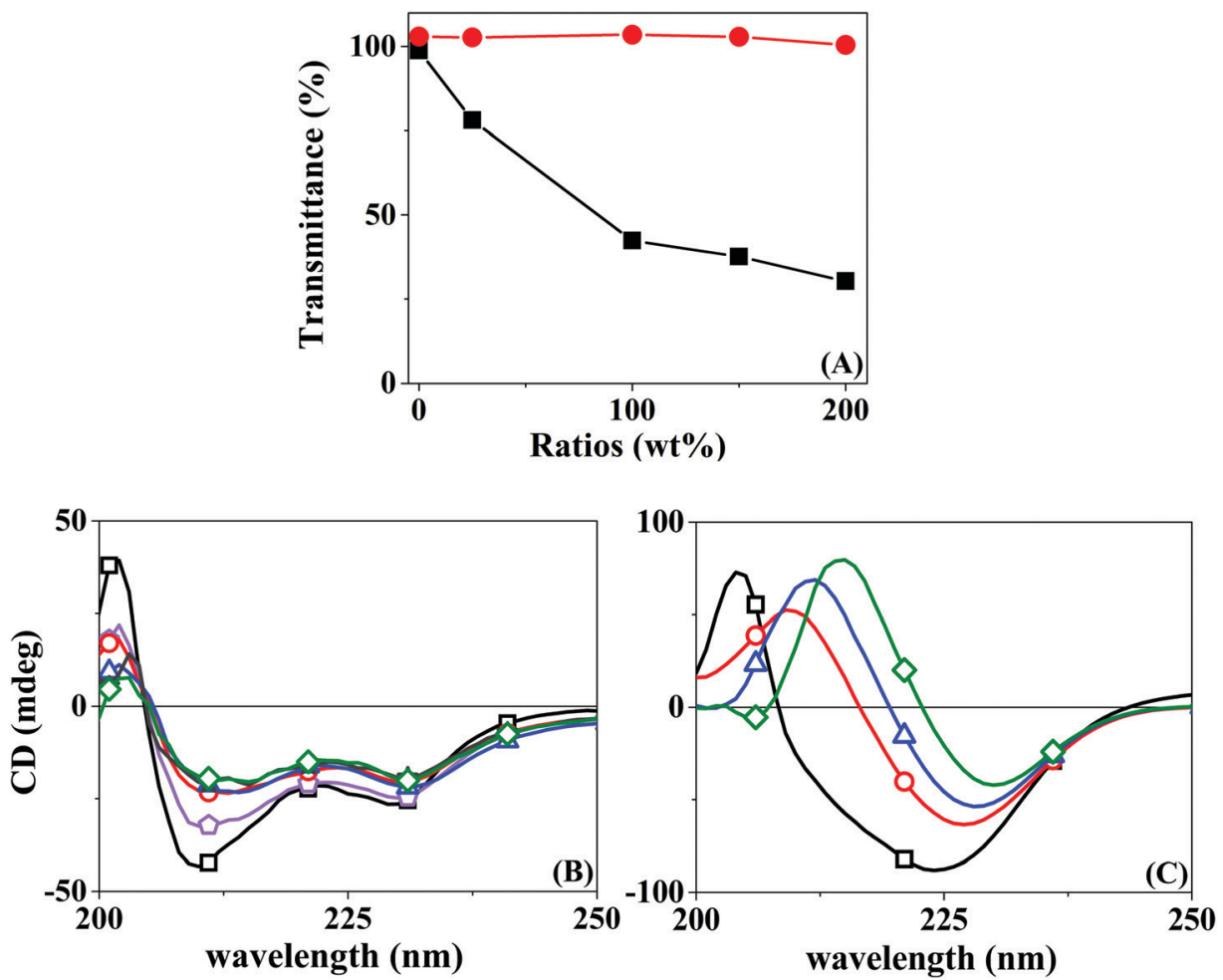

Fig. 1 (A) Turbidimetry assay transmittance at $500 \mathrm{~nm}$ of Hep:LYS (- $\mathbf{-}-)$ ) and Chi:BSA (___ at different polyelectrolyte : protein ratios, from a fixed protein concentration of $0.3 \mathrm{mg} \mathrm{mL}^{-1}$; (B) CD spectra of Hep:LYS and (C) Chi:BSA with a polyelectrolyte : protein ratio of 0 ( $\left.\square-\square\right), 0.25$ (_- _ ), 1.0

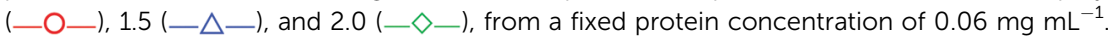


extended chains. ${ }^{29}$ The impact on the protein structure is mostly due to the acidity of the polyelectrolyte solution since Chi is solubilized by the addition of $2 \%$ acetic acid, as shown by the control experiment. Although Takeda et al. ${ }^{30}$ showed a significant decrease in the helical content of a BSA solution at $\mathrm{pH} 2.8$ in the range of $2-65{ }^{\circ} \mathrm{C}$, the changes observed were shown to be fully reversible.

The differences between the two pairs are evident. While by turbidimetry, a test for macrophase separation, Hep and LYS seem to form a complex readily, BSA is less sensitive to the presence of Chi. On the other hand, the CD results show a finite effect of Hep over LYS, but a softer and rising effect of Chi over BSA. In a recent review, Obermeyer et al. ${ }^{31}$ discuss the design parameters for an effective protein-polyelectrolyte complex. The authors claim that "protein charge patchiness" is a crucial factor for coacervate formation. Indeed, the total protein charge is not the only parameter for complex formation. Although the two proteins used here are of opposite charges, as indicated by their pI values, the sizes are rather different. While LYS is a protein of only $14 \mathrm{kD}$ in size, the BSA molecular weight is $66 \mathrm{kD}$.

To quantify the protein-polyelectrolyte interactions studied here, the energy of the complexation process was obtained by using Isothermal Titration Calorimetry (ITC). By applying a one-site model to the obtained results (Fig. 2), the complexation of Hep:LYS was shown to be an exothermic and spontaneous process, reaching a $\Delta H$ value of $-69.1 \pm 0.7 \mathrm{kcal} \mathrm{mol}^{-1}\left(\Delta S=-205 \mathrm{cal} \mathrm{mol}^{-1} \mathrm{deg}^{-1}\right.$, $\Delta G=35.3 \mathrm{kcal} \mathrm{mol}^{-1} \mathrm{~K}^{-1}, K=1.7 \pm 0.1 \times 10^{6} \mathrm{M}^{-1}$ ) with $0.136 \pm$ 0.001 ligation sites for Hep per LYS molecule (Fig. 2A).

On the other hand, the ITC results for the complexation between Chi and BSA (Fig. 2B) showed it to be slightly endothermic. The one site model is not valid in this case since the errors of each parameter are on the same magnitude or higher than the mean value. Therefore, it is possible to extrapolate the heat of interactions to the first injection of polyelectrolyte to calculate $\Delta H,{ }^{32}$ which is $8.5 \mathrm{kcal} \mathrm{mol}^{-1}$, as it is reasonable to assume that approximately $100 \%$ of the polyelectrolyte at this point is bonded to at least one protein of the initial solution. Since the system with BSA and Chi does not correlate with the one-site model, it is likely that no or just a small quantity of polyelectrolyte is complexing with the protein under the conditions of the LbL solutions.

\subsection{Analyses of reservoir assembly by AFM}

LbL assembly on PCL or PLLA coated silicon substrates did not give a clear-cut layer thickness measurement since the polymer material absorbs the energy of the incident laser beam. Hence, multilayers of Hep and Chi were built on bare Si-wafers to have a proper characterization of the LbL assembly by ellipsometry. Fig. 3 shows that the Hep/Chi multilayers or Hep + BSA/Chi and Hep/Chi + LYS reservoirs present an increased thickness profile based on exponential growth (Table 1) when depositing 20 (Fig. 3A) or 10 (Fig. 3B) layer-pairs. In neither case did the inclusion of BSA or LYS influence the growth profile.

The multilayers Hep/Chi, Hep + BSA/Chi, and Hep/Chi + LYS assembled with 20 or 10 layer-pairs on bare Si-wafers were also characterized by AFM measurements. Fig. 3(C-E) show that multilayers with 20 LP (samples $\underline{1}-\underline{3}$ ) have more homogenous topography than multilayers with $10 \mathrm{LP}$ (Fig. 3(F-H); samples 4-6). Smaller r.m.s. values, around $3 \mathrm{~nm}$ for $20 \mathrm{LP}$ multilayers, confirm their reduced roughness when compared to $10 \mathrm{LP}$ multilayers as a consequence of the deposition process. The differences in thickness values obtained by ellipsometry or blade cutting measured by AFM (Table 1) suggest an anisotropic LbL structure due to the introduction of model proteins of BSA or LYS. Moreover, the thickness values determined by AFM show that the reservoirs containing BSA or LYS are thicker than the pristine Hep/Chi multilayers due to the presence of the proteins. BSA inclusion led to a somewhat higher increment of thickness compared to LYS, even when the proteins are included in inner layer pairs, as seen in Table 1 and Fig. 3B.

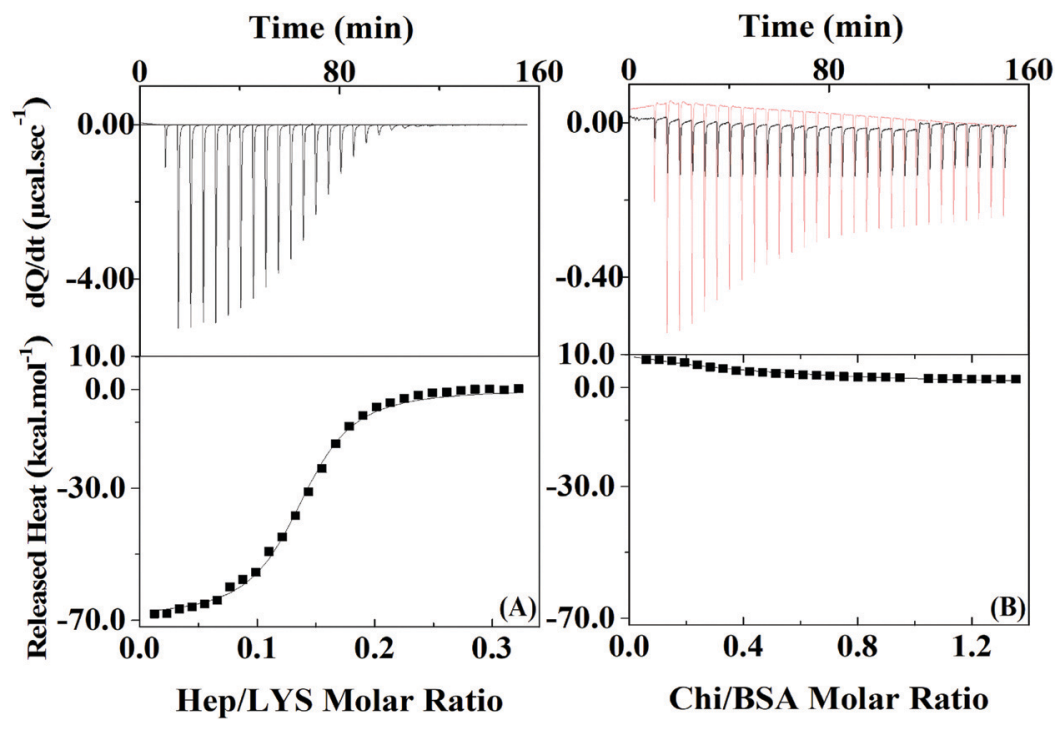

Fig. 2 ITC measurements for Hep:LYS (left) and Chi:BSA (right) at $23^{\circ} \mathrm{C}$ analyzed by the one-site model. Injections of polyelectrolyte were added to an initial protein concentration of $152 \mu \mathrm{M}$ for LYS and $20 \mu \mathrm{M}$ for BSA. 

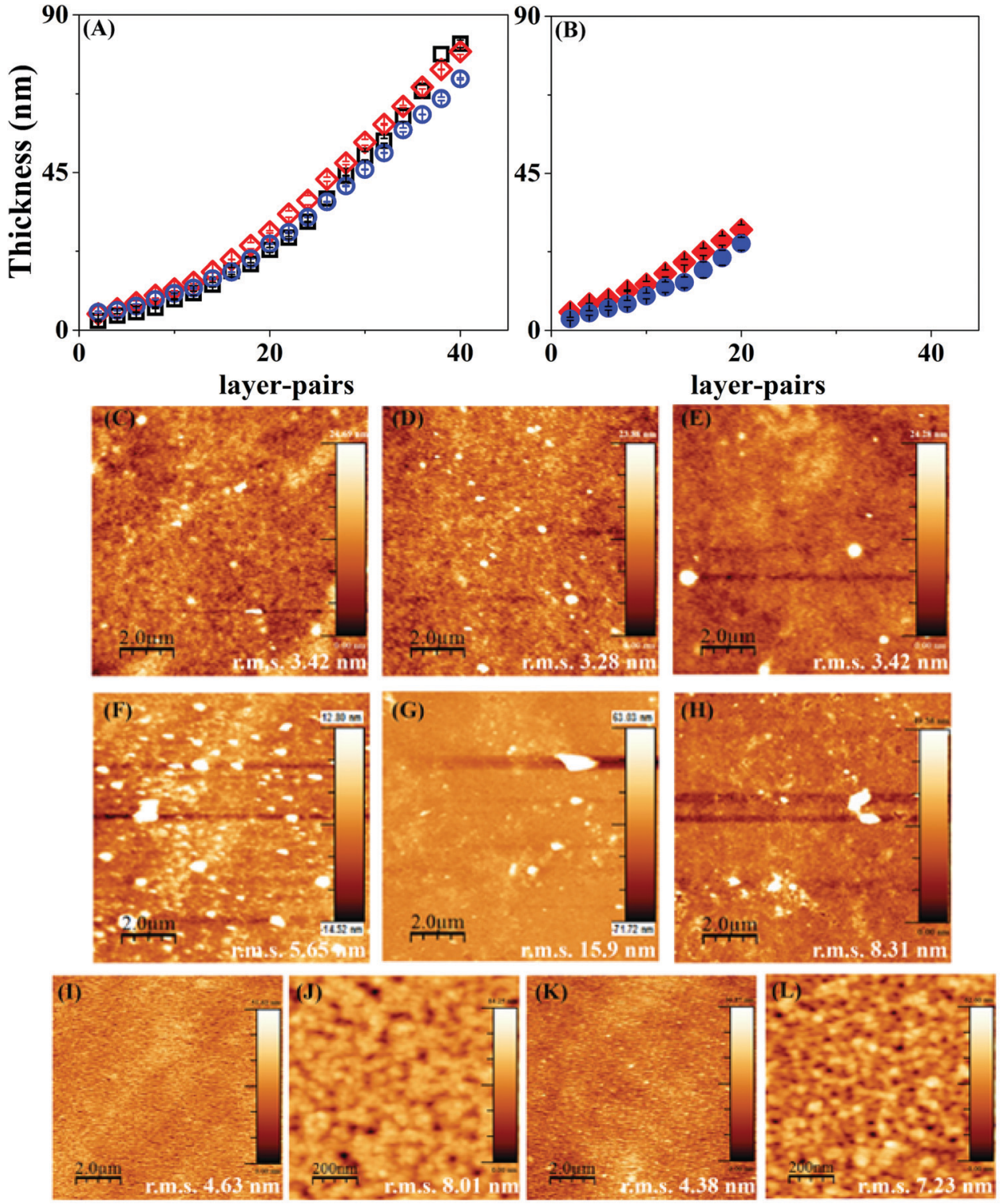

Fig. 3 Ellipsometry measurements for Hep/Chi multilayers with inclusion of BSA and LYS. (A) $\left(\mathrm{Si} / \mathrm{SiO}_{2} / \mathrm{PEI}\right)(\mathrm{Hep} / \mathrm{Chi})_{20}(-\square-),\left(\mathrm{Si} / \mathrm{SiO} \mathrm{O}_{2} / \mathrm{PEI}\right)(\mathrm{Hep}+\mathrm{BSA} /$ $\mathrm{Chi})_{20}\left(\_\diamond —\right),\left(\mathrm{Si} / \mathrm{SiO}_{2} / \mathrm{PEI}\right)(\mathrm{Hep} / \mathrm{Chi}+\mathrm{LYS})_{20}\left(\_\mathrm{O} \_\right) ;(\mathrm{B})\left(\mathrm{Si} / \mathrm{SiO}_{2} / \mathrm{PEI}\right)(\mathrm{Hep} / \mathrm{Chi})_{4}(\mathrm{Hep}+\mathrm{BSA} / \mathrm{Chi})_{3}(\mathrm{Hep} / \mathrm{Chi})_{3}\left(\mathrm{C}_{-}-\right)_{2},\left(\mathrm{Si} / \mathrm{SiO} \mathrm{O}_{2} / \mathrm{PEI}\right)(\mathrm{Hep} / \mathrm{Chi})_{4}(\mathrm{Hep} /$ $\mathrm{Chi}+\mathrm{LYS})_{3}(\mathrm{Hep} / \mathrm{Chi})$ (_- _ ). AFM images for various multilayer configurations. (C) $\left(\mathrm{Si}_{\mathrm{SiO}} / \mathrm{PEI}\right)(\mathrm{Hep} / \mathrm{Chi})_{20},(\mathrm{D})(\mathrm{Si} / \mathrm{SiO} 2 / \mathrm{PEI})(\mathrm{Hep}+\mathrm{BSA} / \mathrm{Chi})_{20},(\mathrm{E})(\mathrm{Si} /$ $\left.\mathrm{SiO}_{2} / \mathrm{PEI}\right)(\mathrm{Hep} / \mathrm{Chi}+\mathrm{LYS})_{20}$, (F) $\left(\mathrm{Si} / \mathrm{SiO}_{2} / \mathrm{PEI}\right)(\mathrm{Hep} / \mathrm{Chi})_{10},(\mathrm{G})\left(\mathrm{Si}_{\mathrm{SiO}} / \mathrm{PEI}\right)(\mathrm{Hep}+\mathrm{BSA} / \mathrm{Chi})_{10},(\mathrm{H})\left(\mathrm{Si} / \mathrm{SiO}_{2} / \mathrm{PEI}\right)(\mathrm{Hep} / \mathrm{Chi}+\mathrm{LYS})_{10}$, (I and J) $\left(\mathrm{Si} / \mathrm{SiO}{ }_{2} / \mathrm{PEI}\right)(\mathrm{Hep} /$ $\mathrm{Chi})_{4}(\mathrm{Hep}+\mathrm{BSA} / \mathrm{Chi})_{3}(\mathrm{Hep} / \mathrm{Chi})_{3},\left(\mathrm{~K}\right.$ and L) $\left(\mathrm{Si}_{\mathrm{SiO}} / \mathrm{PEI}\right)(\mathrm{Hep} / \mathrm{Chi})_{4}(\mathrm{Hep} / \mathrm{Chi}+\mathrm{LYS})_{3}(\mathrm{Hep} / \mathrm{Chi})_{3}$. The scanning areas are $10 \mu \mathrm{m} \times 10 \mu \mathrm{m}$, except for $(\mathrm{J})$ and $(\mathrm{L})$ which are $1 \mu \mathrm{m} \times 1 \mu \mathrm{m}$.

The AFM images of mixtures containing the proteins in inner layers (Fig. 3(I-L); samples $\underline{7}$ and $\underline{8}$ ) show that the additional $3 \mathrm{LP}$ of $\mathrm{Hep} / \mathrm{Chi}$ is enough to render a homogeneous coating on the top of the reservoirs. A similar roughness measured for both samples, around $4 \mathrm{~nm}$ (Fig. 3I and K), supports this observation. Higher magnification scanning (Fig. 3J and L) evidenced a homogeneous topography of the Hep/Chi top layers.

When PCL and PLLA spin-coated films were used as substrates for LbL, the deposition of the PEI first layer was ineffective as compared to using standard Si-wafer conditions. The lack of stability of the LbL assembly thus formed was evident even after increasing tenfold the concentration of PEI (to a $2.5 \mathrm{mg} \mathrm{mL} \mathrm{mL}^{-1}$ solution during $1 \mathrm{~h}$ ), and $\mathrm{Hep} / \mathrm{Chi}$ multilayers started desorbing from the surface of the spin-coated film after three layer-pairs. The AFM images for the PEI first layer after one hour of dipping show aggregates dispersed in the surface of both the PCL (Fig. 4A) and PLLA (Fig. 4C) spin-coated films. The low PEI first layer coating renders a non-homogeneous LbL assembly, and, as a consequence, the multilayers end up desorbing from the polymeric surface.

The production of a stable LbL assembly on top of spincoated films was possible by increasing the PEI dipping time to about 16 hours and using a higher concentration $\left(2.5 \mathrm{mg} \mathrm{mL}^{-1}\right)$ solution. Such observations can be explained by the lower 

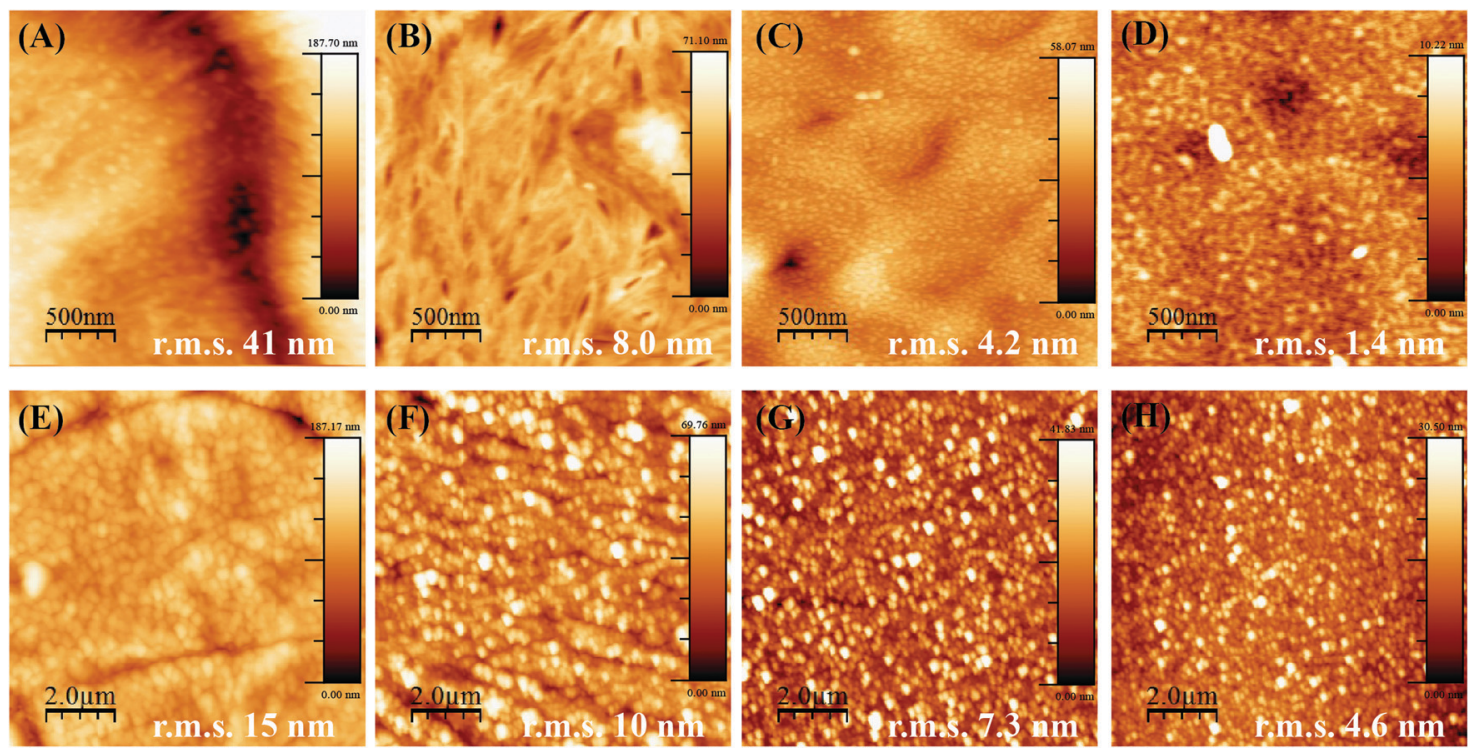

Fig. 4 AFM images for the first PEl layer adsorbed on PCL (1 h: (A), overnight: (B)) or PLLA (1 h: (C), overnight: (D)); scanning areas: $2.5 \mu \mathrm{m} \times 2.5 \mu \mathrm{m}$. AFM images for $(\mathrm{PCL} / \mathrm{PEI})(\mathrm{Hep} / \mathrm{Chi})_{10}$ multilayers prepared with polyelectrolyte solutions at $1 \mathrm{mg} \mathrm{mL}^{-1}(\mathrm{E})$ and $0.1 \mathrm{mg} \mathrm{mL}^{-1}(\mathrm{~F})$; (PLLA/PEI)(Hep/Chi) 10 multilayers prepared with polyelectrolyte solutions at $1 \mathrm{mg} \mathrm{mL}^{-1}(\mathrm{G})$ and $0.1 \mathrm{mg} \mathrm{mL}^{-1}(\mathrm{H})$; scanning areas: $10 \mu \mathrm{m} \times 10 \mu \mathrm{m}$.

interaction of PEI with polymeric films compared to Si-wafers. The electrostatic interactions are replaced by hydrophobic ones, which take more time to be established in non-charged polymeric surfaces. For the samples prepared by overnight dipping in PEI, AFM images evidence a more homogenous PEI layer and a surface of lower roughness (decrease in r.m.s. values) for both PCL (Fig. 4B) and PLLA (Fig. 4D). Based on these observations, the preparation of the PEI first layer from PEI $2.5 \mathrm{mg} \mathrm{mL}^{-1}$ dipping solution overnight was defined as most efficient to build the subsequent LbL multilayers on top of the polymeric films.

Another parameter to control the assembly of Hep/Chi multilayers on top of the polymeric films was the concentration of the polyelectrolytes, here tested at 1 and $0.1 \mathrm{mg} \mathrm{mL}^{-1}$. AFM images evidenced that multilayers prepared from higher concentrations (Fig. 4E and G, for PCL and PLLA, respectively) presented rougher surfaces (higher r.m.s. values) than the ones prepared with diluted solutions (Fig. $4 \mathrm{~F}$ and $\mathrm{H}$, for PCL and PLLA, respectively). The LbL assembly from diluted polyelectrolyte solutions showed a more homogeneous coating of the polymeric surfaces.

Also, the smaller r.m.s. values for multilayers built on PLLA films evidenced a more homogeneous LbL assembly as compared to PCL. This fact is the result of differences in the topography of pure PCL and PLLA after spin-coating. Thin films made of PCL are rougher and display topographic domains due to their higher crystallinity structure (Fig. 5A). Contrarily, PLLA films show flatter surfaces (Fig. 5D) and lower roughness, similar to materials like glass and mica surfaces (r.m.s. values around $0.18 \mathrm{~nm}$ and $0.05 \mathrm{~nm}$, respectively ${ }^{33}$ ). The building of Hep + BSA/Chi or Hep/Chi + LYS reservoirs on top of the polymeric films showed a homogeneous topography after $10 \mathrm{LP}$ (Fig. 5). By comparing the topographic profiles, it is possible to confirm that the BSA and LYS reservoirs were adsorbed on top of PCL (Fig. 5B and C, respectively) and PLLA (Fig. 5E and F, respectively).

The stability of the reservoir assemblies was investigated by increasing the protein concentration in the dipping co-solution. No changes in roughness and topography were observed when comparing the r.m.s. values for the same scanning areas $(2.5 \mu \mathrm{m} \times 2.5 \mu \mathrm{m})$. Reservoirs built on top of PCL films (Fig. S1, ESI $\dagger$ ) present rougher surfaces than PLLA (Fig. S2, ESI $\dagger$ ). However, this seems to be an effect of the PCL rugosity, as evidenced in Fig. 5A. As controls, the Hep/Chi multilayers assembled on top of PCL and PLLA (Fig. S3(A-D) and S3(E-H), respectively, ESI $\dagger$ ) showed smaller r.m.s. values on average than the reservoirs with higher amounts of protein. The detailed AFM images from inside the holes that appear in PLLA - as a consequence of the dewetting process - confirm the assembly of both reservoirs with BSA and LYS (Fig. S3(I-J) and S3(K-L), respectively, ESI $\dagger$ ). The protein position in the reservoir - bottom, middle, or top of the LbL assembly - did not influence the topography of the multilayers adsorbed on PCL and PLLA (Fig. S4 and S5, respectively, ESI $†$ ).

Fluorescence images were obtained for LbL reservoirs prepared with model proteins (Fig. 6(A-D)) or FITC-bound model proteins (Fig. 6(E-H)). LbL assemblies with non-bound proteins did not present fluorescence, while the fluorescent greenish color distributed in the surface, due to the presence of BSAFITC or LYS-FITC, is evidence of the loading of the proteins on the LbL assembly.

\subsection{Analyses of reservoir assembly by QCM-D}

The multilayers and reservoirs were assembled onto a $\mathrm{Au}$ sensor modified by adsorption of PCL and PEI (Au/PCL/PEI). Fig. 7 shows the amount of adsorbed mass $(\Delta m)$ as a function of the layer-pair, for the experimental control (Hep/Chi) and the BSA reservoir (Hep + BSA/Chi) and LYS reservoir (Hep/Chi + LYS). 

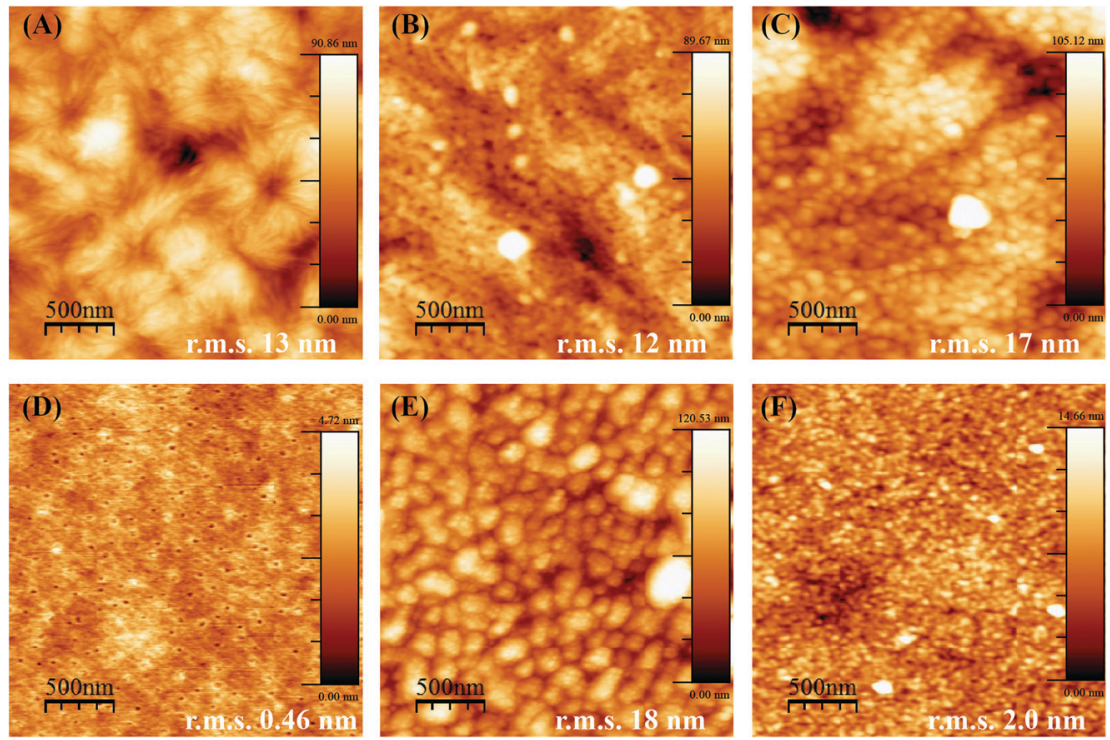

Fig. 5 AFM images for the (A) PCL spin-coated film, (B) (PCL/PEI)(Hep + BSA/Chi) ${ }_{10}$, (C) $(P C L / P E I) /(H e p / C h i+L Y S)_{10}$, (D) the PLLA spin-coated film, (E) $(\mathrm{PLLA} / \mathrm{PEI})(\mathrm{Hep}+\mathrm{BSA} / \mathrm{Chi})_{10}$, (F) (PLLA/PEI)(Hep/Chi + LYS) $)_{10}$. Scanning areas: $2.5 \mu \mathrm{m} \times 2.5 \mu \mathrm{m}$.
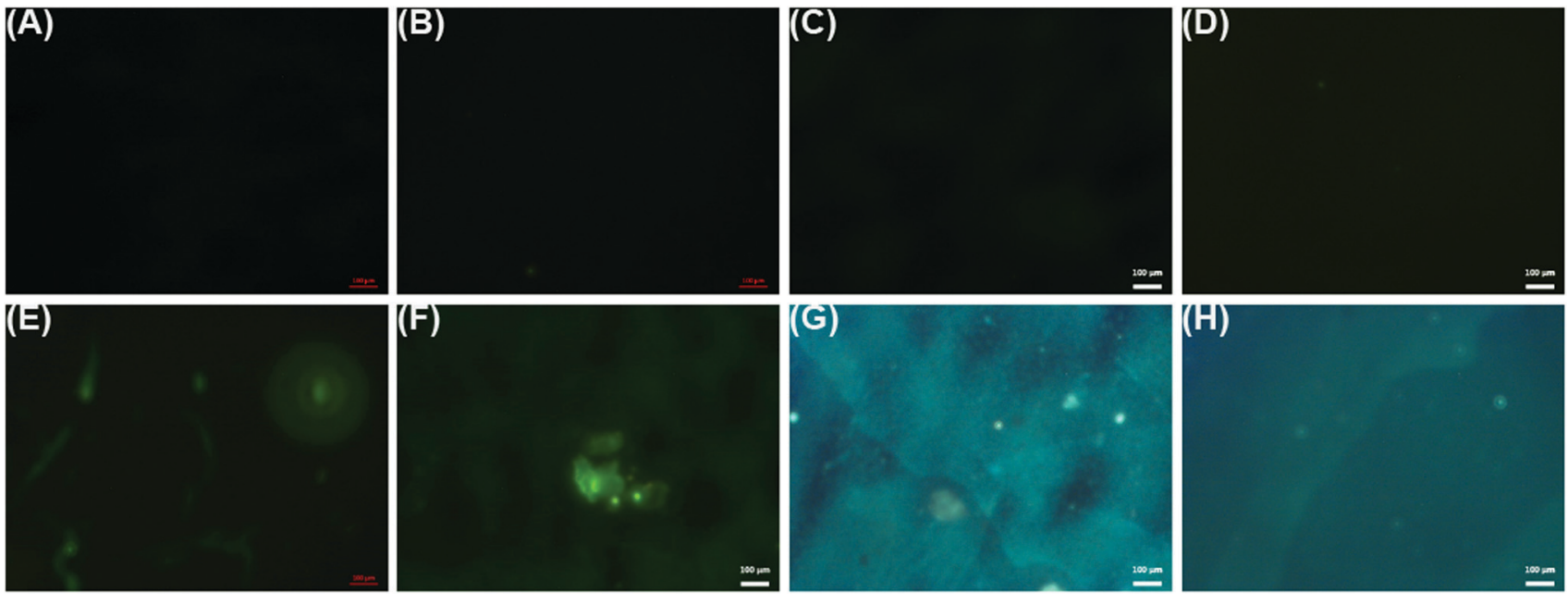

Fig. 6 LbL reservoirs assembled with bare proteins: (A) $\left(\mathrm{PCL}(\mathrm{PEI})(\mathrm{Hep}+\mathrm{BSA} / \mathrm{Chi})_{10}\right)$, (B) $(\mathrm{PLLA} / \mathrm{PEI})(\mathrm{Hep}+\mathrm{BSA} / \mathrm{Chi})_{10},(\mathrm{C})(\mathrm{PCL} / \mathrm{PEI})(\mathrm{Hep} / \mathrm{Chi}+\mathrm{LYS})_{10}$, (D) $(\mathrm{PLLA} / \mathrm{PEI})(\mathrm{Hep} / \mathrm{Chi}+\mathrm{LYS})_{10}$; LbL reservoirs assembled with FITC-bound proteins: (E) (PCL/PEI)(Hep + BSA-FITC/Chi) 10 , (F) (PLLA/PEI)(Hep + BSA-FITC/Chi) ${ }_{10}$, (G) (PCL/PEI)(Hep/Chi + LYS-FITC) ${ }_{10}$, (H) (PLLA/PEI)(Hep/Chi + LYS-FITC) 10 . Scales: $100 \mu \mathrm{m}$.

The different assemblies onto Au/PCL/PEI feature rigidity with low dissipation shifts (Fig. S6, ESI $\dagger$ ), allowing one to apply the Sauerbrey equation (eqn (2)).

The reported values are the average of triplicates of the data for different electrodes with a deviation of $<5 \%$. The adsorption of polyelectrolytes in multilayers (control experiment, blue triangles) and reservoir systems (Hep + BSA/Chi, black squares; Hep/Chi + LYS, red circles) was carried out in $150 \mathrm{mM} \mathrm{NaCl}$ at $25.00 \pm 0.05{ }^{\circ} \mathrm{C}$. The total amount of material adsorbed onto $\mathrm{Au} / \mathrm{PCL} / \mathrm{PEI}$ increases regardless of the protein (BSA or LYS) added to each layer-pair. The multilayers do not present a tendency of an adsorption plateau. At the tenth layer pair, the total mass deposited was $6.0 \pm 0.3 \mu \mathrm{g} \mathrm{cm}^{-2}, 6.7 \pm$ $0.3 \mu \mathrm{g} \mathrm{cm}^{-2}$ and $4.5 \pm 0.2 \mu \mathrm{g} \times \mathrm{cm}^{-2}$ for $(\mathrm{Au} / \mathrm{PCL} / \mathrm{PEI})(\mathrm{Hep} / \mathrm{Chi})_{10}$,
$(\mathrm{Au} / \mathrm{PCL} / \mathrm{PEI})(\mathrm{Hep}+\mathrm{BSA} / \mathrm{Chi})_{10}$ and $(\mathrm{Au} / \mathrm{PCL} / \mathrm{PEI})(\mathrm{Hep} / \mathrm{Chi}+$ LYS $)_{10}$, respectively.

Fig. 8 shows the resonance frequency normalized by the overtone $(\Delta f / n)$ and dissipation for each overtone $\left(\Delta D_{n}\right)$ as a function of time, for the control experiment (Au/PCL/PEI)(Hep/ Chi) (Fig. 8(A and B)), and BSA and LYS reservoirs (Au/PCL/ $\mathrm{PEI})(\mathrm{Hep}+\mathrm{BSA} / \mathrm{Chi})_{2}$ (Fig. $8(\mathrm{C}$ and D) $)$ and $(\mathrm{Au} / \mathrm{PCL} / \mathrm{PEI})(\mathrm{Hep} /$ Chi + LYS $)_{2}$ (Fig. 8(E and F)), respectively. Here, two polyelectrolyte layer-pairs are assembled with a long time of adsorption and rinsing, to evaluate the multilayer stabilization and structure changes during each polyelectrolyte adsorption.

The first layer of Hep (Fig. 8A and E, arrow 1) and Hep + BSA (Fig. 8C, arrow 4) adsorbs over Au/PCL/PEI with a $\Delta f$ decrease of $30 \mathrm{~Hz}$ for the control experiment, $40 \mathrm{~Hz}$ for the BSA reservoir 


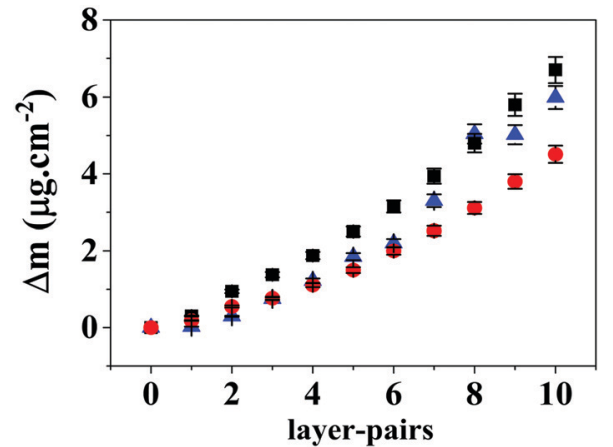

Fig. 7 Amount of deposited mass $(\Delta m)$ as a function of the number of layer-pairs onto $\mathrm{Au} / \mathrm{PCL} / \mathrm{PEl}$ determined at $(25.00 \pm 0.05){ }^{\circ} \mathrm{C}$ for $\mathrm{Hep} / \mathrm{Chi}$ $(\boldsymbol{\Lambda})$, Hep + BSA/Chi $(\mathbb{\square})$ and Hep/Chi + LYS (O). Each point is the average of triplicates \pm SD.

and $44 \mathrm{~Hz}$ for the LYS reservoir. Rinsing with saline solution retains the frequency value for all systems (first arrow 2). However, exchange with Chi (Fig. 8A and C, first arrow 3) or Chi + LYS (Fig. 8E, first arrow 5) causes removal of the Hep layer previously adsorbed, as shown by the second rinse with saline solution (second arrow 2). Despite that, the building of the second layer-pair presents a frequency shift, which indicates new adsorption of Hep or HEP + BSA.

The second adsorption of Chi (Fig. 8A and C, second arrow 3) or Chi + LYS (Fig. 8E, second arrow 5) addition causes a frequency shift until stabilization, with a split in the overtones. This situation is changed during rinsing, likely due to the removal of the superficial Hep or HEP + BSA, leading to a frequency shift of $-104,-70$, and $-74 \mathrm{~Hz}$ for the control experiment, and BSA and LYS reservoirs, respectively. Nevertheless, the rinsing can remove part of the polyanions previously adsorbed, a situation caused by strong complexation between Hep and Chi. ${ }^{34-36}$

The addition of Hep or HEP + BSA in the second bilayer removes the overtone splitting for both reservoirs (Fig. 8C, second arrow 1, and Fig. 8E, second arrow 4). The addition of Chi caused a split in the overtones for all the systems. Similar behavior was observed by Lundin and Kovacevic in layer-bylayer assemblies built with different polyelectrolytes. ${ }^{23,25}$ They attributed that phenomenon to the redissolution of complexes induced by strong complexation between the polyanion and polycation, likely due to hydrogen bonding between the carboxyl residue group of Hep and amino residue group of Chi. However, after the removal of the shallow Hep layer, Chi might diffuse into the thin film matrix of the deposited polyanion to find an electrostatic cross-linking partner. A more refined discussion on additional aspects shown by the results of Fig. 8 is presented in the ESI. $\dagger$

Richert et al. reported similar phenomena in QCM-D responses for $\mathrm{Au} /(\mathrm{Chi} / \mathrm{HA})_{36} \cdot{ }^{24}$ Through the confocal laser microscopy technique, the authors showed fluorescently labeled Chi
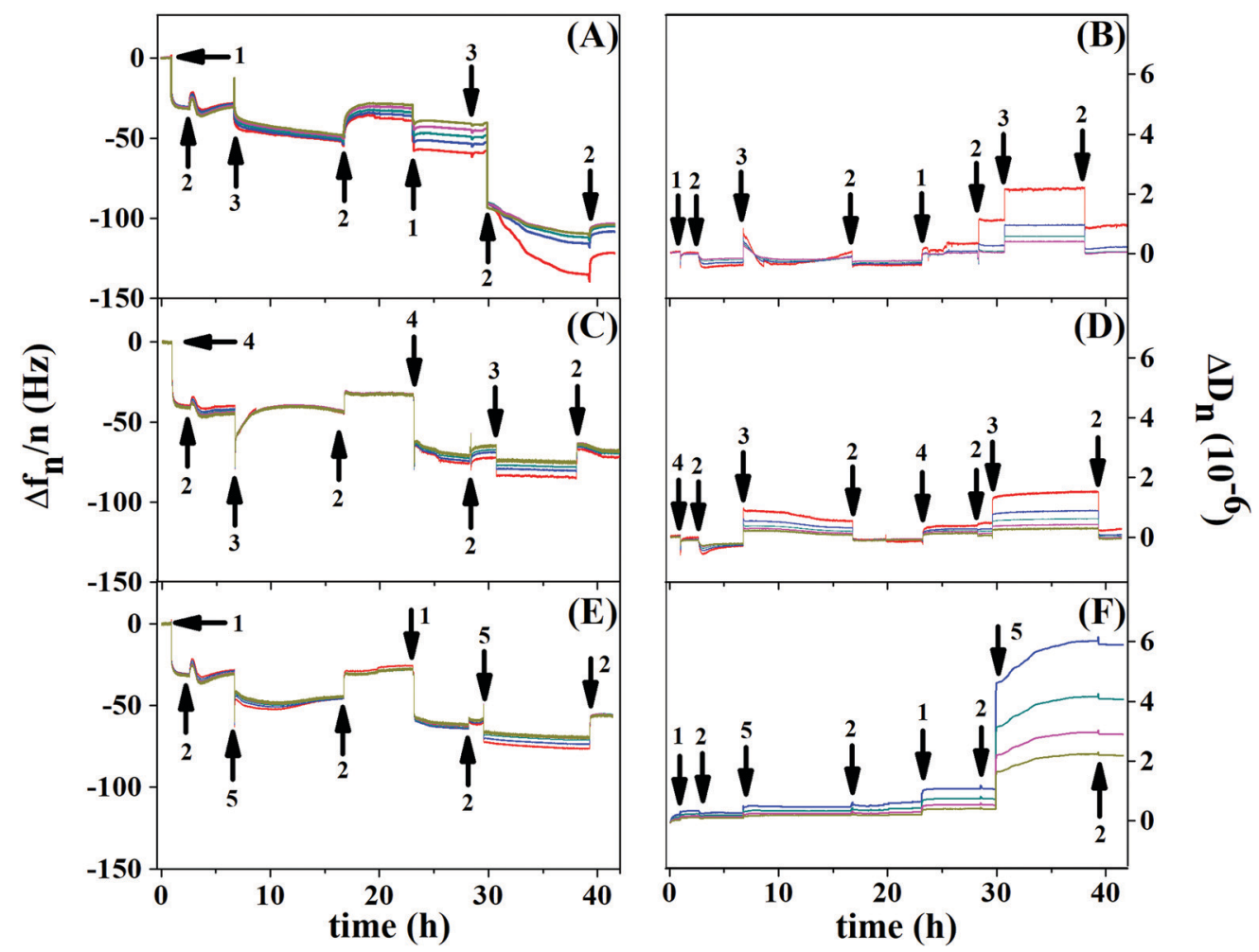

Fig. $8 \mathrm{QCM}-\mathrm{D}$ in situ response given by $\Delta f_{n} / n(\mathrm{~A}, \mathrm{C}$ and $\mathrm{E})$ and $\Delta D_{n}(\mathrm{~B}, \mathrm{D}$, and $\mathrm{F})$ as a function of time for two layer-pairs for $(\mathrm{Au} / \mathrm{PCL} / \mathrm{PEI})(\mathrm{Hep} / \mathrm{Chi})_{2}$ $(\mathrm{A}$ and $\mathrm{B}),(\mathrm{Au} / \mathrm{PCL} / \mathrm{PEI})(\mathrm{Hep}+\mathrm{BSA} / \mathrm{Chi})_{2}(\mathrm{C}$ and $\mathrm{D})$ and $(\mathrm{Au} / \mathrm{PCL} / \mathrm{PEI})(\mathrm{Hep} / \mathrm{Chi}+\mathrm{LYS})_{2}(\mathrm{E}$ and F), respectively. The overtones ( $n)$ are 5 (red), 7 (blue), 9 (dark cyan), 11 (magenta), and 13 (dark yellow) for the eight steps involved in the modification of the gold substrates. Arrows 1, 2, 3, 4, and 5 indicate the addition of Hep, saline solution, Chi, Hep + BSA, and Chi + LYS, respectively. 
migrating inside the multilayers during their formation, while hyaluronan labeled (HA) remains fixed without migration. ${ }^{24}$ In our study, the diffusion of Chi into Hep fixed layers might cause a decrease in stiffness for the first layer-pair of the control system. Nevertheless, during the deposition of the following polyelectrolyte, a recovery of stiffness was observed, perhaps justified by associated events, such as an increase of density, ${ }^{23,25}$ demonstrated by dissipation frequencies smaller than $10 \mathrm{~Hz}$ (Fig. 8B, D, and F).

A similar QCM-D procedure to that applied to PCL was tried for PLLA; however, the PLLA film detached from the Au sensor because it swelled by absorbing water during the deposition of PEI, preventing the analysis.

\subsection{Protein release assays}

Considering that the Hep layers stay fixed while the Chi shifts through the multilayer (Section 3.3), therefore, keeping levels of intermixing of the layers and stratification, we propose here a control of the release dynamics by changing the relative position at which the protein is placed inside the reservoir. Three different configurations were designed using an assembly of 10 layer-pairs (Scheme 1): (a) (Hep/Chi $)_{5}(\mathrm{Hep}+\mathrm{BSA} / \mathrm{Chi})_{5}$ and $(\mathrm{Hep} / \mathrm{Chi})_{5}\left(\mathrm{Hep} /(\mathrm{Chi}+\text { LYS-FITC })_{5}\right)$ where both proteins were loaded on the top 5 layer-pairs; (b) [(Hep/Chi)(Hep + BSA/ Chi $)]_{5}$ and $[(\mathrm{Hep} / \mathrm{Chi})(\mathrm{Hep} /(\mathrm{Chi}+\mathrm{LYS}-\mathrm{FITC}))]_{5}$ when 5 layers of proteins were evenly distributed within the 10 layer-pair assembly; and (c) $(\mathrm{Hep}+\mathrm{BSA} / \mathrm{Chi})_{5}(\mathrm{Hep} / \mathrm{Chi})_{5}$ and (Hep/ $\left.(\text { Chi }+ \text { LYS-FITC })_{5}(\text { Hep/Chi })_{5}\right)$, where the proteins were loaded on the bottom 5 layer-pairs. The reservoirs for the release assays were assembled using dipping co-solutions of the polyelectrolytes containing protein concentrations of $100 \mu \mathrm{g} \mathrm{mL} \mathrm{m}^{-1}$ and release assays were performed in PBS at $37{ }^{\circ} \mathrm{C}$ in order to simulate physiological conditions.

The release of LYS was monitored by fluorescence using an FITC-labeled protein, since the functionalization process promoted only a light change of its $\mathrm{pI}$, from 10.3 to 10.5 . The release of BSA was monitored by immunofluorescence using BSA ELISA since the functionalization promoted an expressive drop of 0.8 of its isoelectric point (from 5.1 to 4.3 ), which risks a divergent situation of protein distribution.
Fig. 9A and B show the BSA release profiles from PCL and PLLA films. All profiles are similar and display an initial burst of around 0.1 to $0.3 \mathrm{ng} \mathrm{cm} \mathrm{cm}^{-2}$ released after $3 \mathrm{~h}$, followed by sustained release that reaches a plateau at about $0.8 \mathrm{ng} \mathrm{cm}^{-2}$ of BSA after 15 days, for both polymeric surfaces. Reservoirs assembled on PCL films with the protein loaded in the top 5 layer-pairs exhibited release slightly faster than the other two configurations. No significant differences were observed between BSA loaded on the bottom layers or evenly distributed. When the PLLA film was the support, no differences can be pinpointed among the three configurations. The amount of BSA released from PLLA reservoirs is somewhat lower than from PCL reservoirs. This result suggested that the surface of the base substrate (polymer) also plays a central role in the LbL self-assembly.

LYS (pI 11.5) was labeled with FITC (LYS-FITC, pI 11.3), a fluorescent probe, to enable the monitoring of its release by fluorescence techniques. Fig. 9C and D show LYS-FITC release profiles from the different multilayer architectures built on PCL and PLLA films, respectively. Similar to BSA, all reservoirs initially showed burst release followed by sustained release of LYS-FITC, reaching a plateau over 15 days. The final amount of LYS-FITC released from the PCL supports gradually decreased in the following order of reservoirs: protein in the top layers, protein evenly distributed, and protein in the bottom layers. This result indicated that a higher amount of LYS protein could be stored in the top layers. Moreover, the reservoir on the PCL substrate showed a significantly higher amount of LYS-FITC released compared to the PLLA film, somewhat repeating the observation from the BSA loaded reservoirs.

The amount of BSA or LYS released from the PLLA reservoirs is somewhat lower than from the PCL reservoirs. Here, the surface of the polymer substrate seems to play a role by showing different specific surface area. Although using the same spin-coating conditions, the PCL film presented high rugosity (r.m.s. $=13 \mathrm{~nm}$ ), likely due to the presence of spherulite-like crystals, not present in PLLA (r.m.s. $=0.46 \mathrm{~nm}$ ) as observed by AFM (Fig. 5A and D). According to Wu et al., ${ }^{37}$ the strong interaction between PLLA and $\mathrm{CHCl}_{3}$ precludes crystal formation. ${ }^{37,38}$

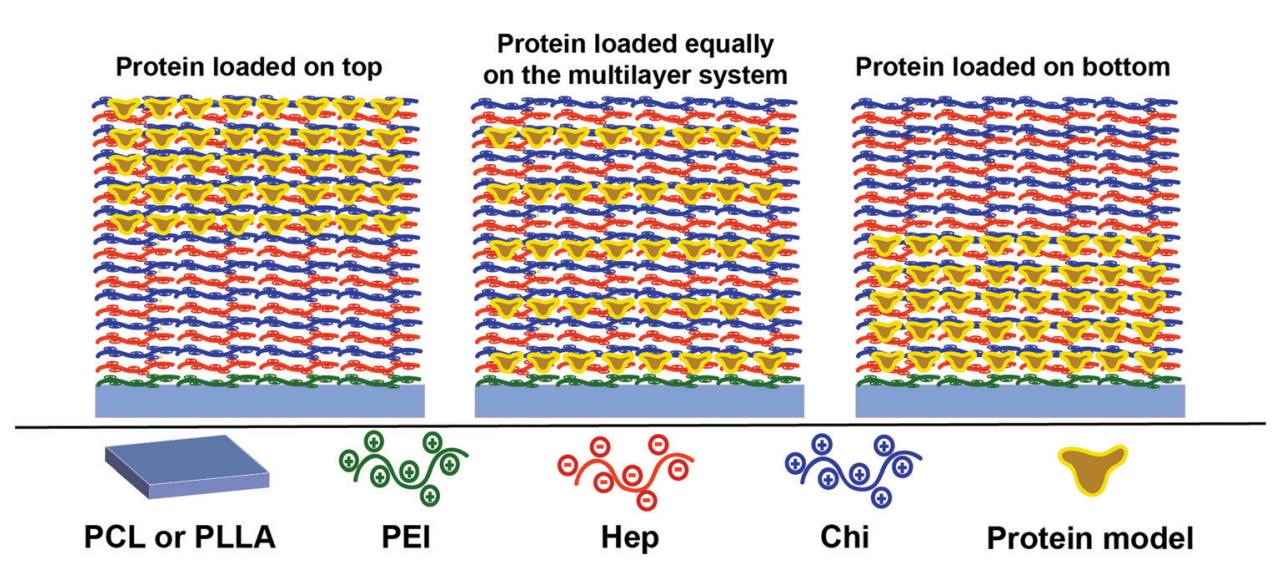

Scheme 1 LbL reservoirs applied for the BSA and LYS release studies. 

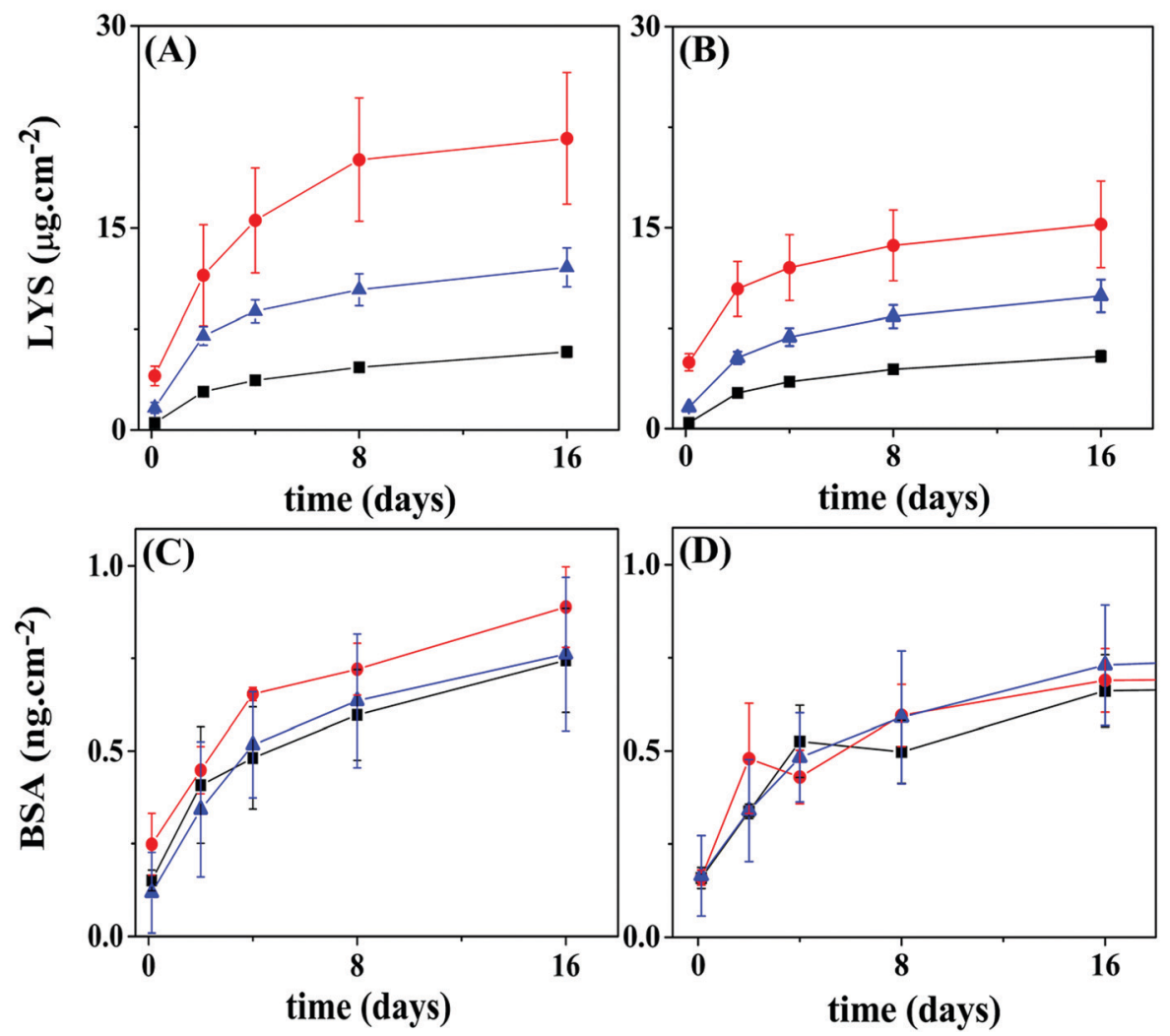

Fig. 9 Release profiles for BSA or LYS from 10 layer pairs of Hep/Chi LbL reservoirs built onto PCL or PLLA films. Proteins were placed within the 5 top layers (red circles), evenly distributed (blue triangles), or within the 5 bottom layers (black squares) of the reservoirs. (A) LYS-FITC reservoir on a PCL substrate; (B) LYS-FITC reservoir on a PLLA substrate; (C) BSA reservoir on a PCL substrate; (D) BSA reservoir on a PLLA substrate. Statistical information is provided in Fig. S7 (ESI†).

As shown in Fig. 9, LYS achieved a total release of four orders of magnitude higher than BSA for the same concentration $\left(100 \mu \mathrm{g} \mathrm{mL}^{-1}\right)$ of the dipping solution. Generally, the rinsing process removes the unbound polyelectrolyte or protein molecules. Alternatively, a polyelectrolyte of opposite charge also operates to remove free or loose charged molecules from the surface, as confirmed here by the QCM-D results. Once inside of the inner layers of the reservoir, the protein would - in theory - be protected from ejection, unless diffusion to the outer layers takes place. A diffusion/redistribution process within the ten layer-assembly, leading to loss of protein during the construction process, can also explain the results shown in Fig. 9. Assuming that the same amount of protein is included during a single loading cycle - five protein-loading cycles in all the configurations - the number of rinsing cycles which each load would be submitted to, i.e., "leaking cycles", would differentiate the three configurations. For example, the last protein-loading cycle of the "5-bottom" would be submitted to 6 extra rinsing cycles, while the last protein-loading cycle of the "5-top" has only one rinsing cycle ahead. This picture is essentially the same for PLLA as the polymeric substrate.

A shallow intermixing of either polyelectrolyte diffusing into the matrix was detected by QCM-D experiments (Fig. 8), an event observed during the deposition of the 1st and 2nd layers. As the assembly grows to a higher number of layers, the intermixing should grow further in distance to the original positioning. The same behavior is expected for the proteins; however, with different amplitudes since they interact dissimilarly with the LbL assemblies. The turbidimetry (Fig. 1) and ITC (Fig. 2) results show a rather distinct complexing capacity of each protein. The release kinetics (Fig. 9) can be viewed as a representation of this distinct intermixing event: (i) highly precluded for LYS (a tightly bound protein), resulting in different kinetics for different positioning (Fig. 9A and B), and (ii) more prominent for BSA (a loose and free molecule within the LbL assembly), when intermixing equalizes the "bottom vs. top" positioning approach (Fig. 9C and D).

When considering these profiles, the release mechanism is based on the dismantling of LbL multilayers following a physical erosion model, where the gradual disruption of electrostatic interactions can lead to the gradual release of both polyelectrolytes and proteins embedded in the reservoirs, ${ }^{7}$ combined with a diffusion/redistribution process. In our previous work, we observed thickness loss by ellipsometry measurements for bare Hep/Chi multilayers and FGF reservoirs after seven days of incubation, ${ }^{18}$ which indicates erosion-controlled release. Other studies also reported similar release behavior for multilayers comprised of different polyamines, ${ }^{7-9}$ where the release occurs by gradual hydrolysis of weak polyacids and subsequent gradual disruption of the physical electrostatic interactions in the multilayer. 
Assessing the volume charge densities of both proteins at the loading $\mathrm{pH}$ also shines some light on the differences observed. While BSA is assumed to present a prolate ellipsoid shape with 14.1 and $4.2 \mathrm{~nm}$ for the $c$ and $a$ axes, ${ }^{39}$ LYS shows a spheroid shape with a hydrodynamic radius of $1.89 \mathrm{~nm} .{ }^{40}$ By using PROPKA software, ${ }^{41} \mathrm{p} K_{\mathrm{a}}$ predictor software, a total charge of -29.3 and +23.4 was calculated for BSA and LYS at the loading $\mathrm{pH}$ (6.7 and 3.0, respectively). These numbers lead to total volume charge densities of 35.9 and $132.3 \mathrm{C} \mathrm{cm}^{-3}$ (in modulus) for BSA and LYS, respectively, demonstrating that LYS is 3.7 times more densely charged, hence explaining the higher loading of LYS.

\section{Conclusions}

An LbL framework made from a multilayer of alternating charged polyelectrolytes heparin and chitosan was used to store BSA and LYS on biodegradable polyester films like PCL and PLLA. The proteins were chosen based on their interactions with the layer of opposite charge, considering its total charge (positive or negative) at the dipping solution $\mathrm{pH}$. The results observed for the two pairs of Hep/LYS and Chi/BSA are strikingly different. Higher binding activity was observed for Hep and LYS, in clear opposition to that between BSA and Chi. Here, the total size and total charge of the protein must be at play. Indeed, LYS presents a volume charge density almost four-fold higher than BSA. The release of protein from the reservoir was controlled by building different architectures of the protein layer in between multilayers on top of PCL and PLLA substrates, demonstrating a novel key-approach to produce LbL-based protein reservoirs. The choice of positioning the same amount of protein within the bottom five layers or in the top five layers can result in clearly different release profiles.

The analysis of the in vitro loading/release profile suggests that the protein delivery can be adjusted by precise positioning within the LbL assembly, demonstrating the importance of planning the material, as well as its architecture. An essential feature of this study was to show the significance of the total charge density of the protein and its interaction with the polyelectrolyte pairs. The total volume charge density of the protein (size versus total protein charge at the loading solution $\mathrm{pH}$ ) is a crucial factor in controlling the total load, stability, and release kinetics. These findings will help in planning a device based on the size and charge of the protein, as well as the choice of the polyelectrolyte, in constructing LbL reservoirs for protein release.

\section{Conflicts of interest}

There are no conflicts to declare.

\section{Acknowledgements}

The authors acknowledge the Fundação de Amparo à Pesquisa do Estado de São Paulo (FAPESP), Brazil (Grants 2011/21442-6, 2015/10009-0, 2015/19694-8, 2017/06394-1, 2018/13492-2,
2018/14532-8), and Conselho Nacional para o Desenvolvimento Científico e Tecnológico (CNPq), Brazil (Grants 4001145/2014-6, $302152 / 2017-2)$, for financial support.

\section{References}

1 J. Hong, B.-S. Kim, K. Char and P. T. Hammond, Biomacromolecules, 2011, 12, 2975-2981.

2 R. C. Smith, A. Leung, B.-S. Kim and P. T. Hammond, Chem. Mater., 2009, 21, 1108-1115.

3 B.-S. Kim, S. W. Park and P. T. Hammond, ACS Nano, 2008, 2, 386-392.

4 L. Gu, Z. J. Deng, S. Roy, P. T. Hammond, C. A. Paula, T. Hammond and D. H. Koch, Clin. Cancer Res., 2017, 23, 7312-7323.

5 A. vander Straeten, A. Bratek-Skicki, A. M. Jonas, C.-A. Fustin and C. Dupont-Gillain, ACS Nano, 2018, 12, 8372-8381.

6 G. Decher, Science, 1997, 277, 1232-1237.

7 N. E. Vrana, A. Dupret-Bories, C. Chaubaroux, E. Rieger, C. Debry, D. Vautier, M.-H. Metz-Boutigue and P. Lavalle, J. Visualized Exp., 2013, 1-9.

8 W. Li, P. Zhao, C. Lin, X. Wen, E. Katsanevakis, D. Gero, O. Félix and Y. Liu, Biomacromolecules, 2013, 14, 2647-2656.

9 X. He, Y. Wang and G. Wu, Appl. Surf. Sci., 2012, 258, 9918-9925.

10 R. Hashide, K. Yoshida, Y. Hasebe, M. Seno, S. Takahashi, K. Sato and J.-I. Anzai, J. Nanosci. Nanotechnol., 2014, 14, 3100-3105.

11 R. Luo, S. S. Venkatraman and B. Neu, Biomacromolecules, 2013, 14, 2262-2271.

12 N. J. Shah, M. N. Hyder, M. A. Quadir, N.-M. Dorval Courchesne, H. J. Seeherman, M. Nevins, M. Spector and P. T. Hammond, Proc. Natl. Acad. Sci. U. S. A., 2014, 111, 12847-12852.

13 L. Keller, S. Eap, J. Schiavi, O. Huck, L. Jacomine, C. Gauthier, V. Sebastian, P. Schwinté, N. Jessel and F. Fioretti, Int. J. Nanomed., 2015, 1061.

14 C. D. Easton, A. J. Bullock, G. Gigliobianco, S. L. McArthur and S. Macneil, J. Mater. Chem. B, 2014, 2, 5558-5568.

15 D. P. Go, J. A. Palmer, G. M. Mitchell, S. L. Gras and A. J. O'Connor, J. Biomed. Mater. Res., Part A, 2015, 103, 1849-1863.

16 D. Chen, M. Wu, J. Chen, C. Zhang, T. Pan, B. Zhang, H. Tian, X. Chen and J. Sun, Langmuir, 2014, 30, 13898-13906.

17 G. Gigliobianco, C. K. Chong and S. MacNeil, J. Biomater. Appl., 2015, 30, 50-60.

18 A. F. Naves, M. Motay, R. Mérindol, C. P. Davi, O. Felix, L. H. Catalani and G. Decher, Colloids Surf., B, 2016, 139, 79-86.

19 R. Signini and S. P. C. Filho, On the preparation and characterization of chitosan hydrochloride, 1999, vol. 42.

20 R. M. A. Azzam and N. M. Bashara, Ellipsometry and polarized light, North-Holland, 1987.

21 L. E. Valenti, V. L. Martins, E. Herrera, R. M. Torresi and C. E. Giacomelli, J. Mater. Chem. B, 2013, 1, 4921-4931.

22 A. H. B. Dourado, R. A. Silva, R. M. Torresi, P. T. A. Sumodjo, M. Arenz and S. I. Cordoba de Torresi, ChemPhysChem, 2018, 19, 2340-2348. 
23 M. Lundin, F. Solaqa, E. Thormann, L. Macakova and E. Blomberg, Langmuir, 2011, 27, 7537-7548.

24 L. Richert, P. Lavalle, E. Payan, X. Z. Shu, G. D. Prestwich, J.-F. Stoltz, P. Schaaf, J.-C. Voegel and C. Picart, Langmuir, 2004, 20, 448-458.

25 D. Kovacevic, S. van der Burgh, A. de Keizer and M. A. Cohen Stuart, Langmuir, 2002, 18, 5607-5612.

26 I. Horcas, R. Fernández, J. M. Gómez-Rodríguez, J. Colchero, J. Gómez-Herrero and A. M. Baro, Rev. Sci. Instrum., 2007, 78, 013705.

27 P. Billsten, M. Wahlgren, T. Arnebrant, J. McGuire and H. Elwing, J. Colloid Interface Sci., 1995, 175, 77-82.

28 T. Peters, R. G. Reed, R. C. Feldhoff and O. L. Clute, Biochemistry, 1975, 14, 4578-4583.

29 B. Ranjbar and P. Gill, Chem. Biol. Drug Des., 2009, 74, 101-120.

30 K. Takeda, A. Wada, K. Yamamoto, Y. Moriyama and K. Aoki, J. Protein Chem., 1989, 8, 653-659.

31 J. Horn, R. Kapelner and A. Obermeyer, Polymers, 2019, 11, 578 .
32 X. Wang, K. Zheng, Y. Si, X. Guo and Y. Xu, Polymers, 2019, 11, 1-18.

33 M. J. Sherratt, D. F. Holmes, C. Adrian Shuttleworth and C. M. Kielty, Biophys. J., 2004, 86, 3211-3222.

34 T. Hattori, K. Kimura, E. Seyrek and P. L. Dubin, Anal. Biochem., 2001, 295, 158-167.

35 M. Rodahl, F. Höök, A. Krozer, P. Brzezinski and B. Kasemo, Rev. Sci. Instrum., 1995, 66, 3924-3930.

36 M. D. Levi, N. Shpigel, S. Sigalov, V. Dargel, L. Daikhin and D. Aurbach, Electrochim. Acta, 2017, 232, 271-284.

37 N. Wu, S. Lang, H. Zhang, M. Ding and J. Zhang, J. Phys. Chem. B, 2014, 118, 12652-12659.

38 M. Sun, P. J. Kingham, A. J. Reid, S. J. Armstrong, G. Terenghi and S. Downes, J. Biomed. Mater. Res., 2009, 93, 1470-1481.

39 A. K. Wright and M. R. Thompson, Biophys. J., 1975, 15, 137-141.

40 A. S. Parmar and M. Muschol, Biophys. J., 2009, 97, 590-598.

41 M. H. M. Olsson, C. R. SØndergaard, M. Rostkowski and J. H. Jensen, J. Chem. Theory Comput., 2011, 7, 525-537. 